\title{
Artikkeli
}

\section{Suomalaisten luottamus instituutioihin ja asiantuntijoihin COVID19-pandemiassa}

\begin{abstract}
Tässä tutkimuksessa selvitämme suomalaisten luottamusta instituutioihin, asiantuntijoihin ja uutismediaan koronakriisin käsittelyssä sekä yksilön vapauteen ja vastuuseen liittyviä asenteita huhtikuussa ja kesäkuussa 2020. Tulosten mukaan suomalaiset luottivat varsin vahvasti hallitukseen, viranomaisiin sekä THL:n ja yliopistojen tutkijoihin kriisin käsittelyssä. Samoin Yle Uutisiin ja MTV Uutisiin luotettiin kriisin raportoinnissa. Enemmistö vastaajista pyrki noudattamaan viranomaisohjeita ja hyväksyi yksilöiden vapauksien rajoitukset epidemian hallitsemiseksi. Enemmistö piti koronarokotuksista kieltäytyjiä vastuuttomina, mutta samalla enemmistö uskoi, että koronarokotusten tulisi olla vapaaehtoisia. Tutkimme tarkemmin sitä, ketkä luottivat eniten ja ketkä vähiten mainittuihin tahoihin. Naiset suhtautuvat miehiä myönteisimmin THL:n toimintaan ja Yle Uutisiin, miehet puolestaan sosiaalisen median vaikuttajiin. Perussuomalaiset erosivat lähes kaikkien muuttujien suhteen muista puolueista: he olivat kriittisimpiä THL:ää, STM:ää, Yle Uutisia sekä viranomaisten rokotetietoa kohtaan. Lopuksi pohdimme, miten voimme näiden tulosten valossa tulkita väitteitä tieteen ja asiantuntijoiden arvostuksen laskusta. Pohdimme myös sitä, muuttiko koronakriisi suomalaisten suhtautumista kansallisiin instituutioihin.
\end{abstract}

AVAINSANAT: COVID19, tiede, asiantuntijat, puolueet, rokotukset

$\mathrm{V}$

uonna 2020 poliittista päätöksentekoa ja mediamaisemaa väritti vahvasti COVID19- eli koronapandemia. Tauti saapui Suomeen tammikuun 2020 lopulla, kun kiinalaisella turistilla diagnosoitiin COVID19-infektio Lapissa. Tämän jälkeen Suomessa seurattiin tilanteen kehittymistä Euroopassa. Epidemiatilanne heikkeni Suomessakin maaliskuun aikana niin, että 17.3.2020 Suomessa astui voimaan valmiuslaki. Sen seurauksena muiden muassa julkisia kokoontumisia ja ravintoloiden toimintaa rajoitettiin, koulut siirtyivät etäopetukseen ja matkustusrajoitus astui voimaan. (Tiirinki ym. 2020)

Maaliskuussa 2020 näytti siltä, että asiantuntijat, oppositio ja kansalaiset seisovat yhtenä rintamana hallituksen tukena (esim. HS 12.4.2020; Saarikoski 2020). Kuitenkin samaan aikaan asiantuntijoihin, virkamiehiin ja ministereihin kohdistui varsin kovaa kritiikkiä uutismediassa ja sosiaalisessa mediassa, eivätkä kaikki luottaneet asiantuntijoiden viesteihin ja 
viranomaisten päätösten perusteluihin (esim. Sadeoja 2020; Ukkola 2020). Twitterissä etenkin Terveyden ja hyvinvoinnin laitos (THL) oli kritiikin kohteena (Väliverronen ym. 2020; Väliverronen 2021). Sitä arvosteltiin epidemian vähättelystä varsinkin epidemian alkuvaiheessa ja myöhemmin siitä, että se painotti epidemian hillintää, kun taas osa tutkijoista ja terveydenhuollon ammattilaisista vaati epidemian tukahduttamista (Eroon koronasta 2020; Walker ym. 2020). Sosiaalisessa mediassa monet vaihtoehtoiset terveysvaikuttajat kommentoivat THL:n ja Suomen hallituksen koronaohjeita ja epidemian kulkuun liittyviä ennusteita ja esittivät omia näkemyksiään koronan torjunnasta. Esimerkiksi lääkäri Antti Heikkilä (2020) kirjoitti blogissaan "Covid-19 vedätyksestä" ja tarkoitushakuisesta paniikin lietsomisesta. Toinen suosittu vaihtoehtoinen terveysvaikuttaja Maria Nordin (2020) varoitti viruspaniikin aiheuttavan stressiä ja olevan siksi vaara terveydelle.

Koronakevään asetelma on kiinnostava: miten nopeasti muuttuva, dramaattisesti etenevä tilanne vaikutti suomalaisten institutionaalisia toimijoita koskevaan luottamukseen sekä käsityksiin yhteisöllisestä ja yksilön vastuusta?

Tässä artikkelissa analysoimme suomalaisten luottamusta kansallisiin instituutioihin ja asiantuntijoihin (hallitus, tasavallan presidentti, sosiaali- ja terveysministeriö, viranomaiset, THL, yliopistot) sekä mediaan (tässä tutkimuksessa Yle Uutiset ja MTV Uutiset ja sosiaalisen median vaikuttajat) koronaepidemian aikana sekä luottamuksessa tapahtuneita muutoksia kevään 2020 aikana. Erityisesti tutkimme sitä, mitkä tekijät olivat yhteydessä luottamukseen ja epäluottamukseen. Tutkimme myös näkemyksiä yhteisvastuusta ja yksilöiden vastuusta koronaepidemian hoidossa.

Pohjaamme tutkimuksemme kolmeen, osin päällekkäiseen tieteelliseen keskusteluun, joiden teemoja ovat: instituutioita koskeva luottamus, asenteet tiedettä ja asiantuntijoita kohtaan sekä mediakentän viimeaikaiset murrokset. Esittelemme seuraavaksi tätä kirjallisuutta, jonka jälkeen siirrymme aineiston ja menetelmien kuvaukseen ja tuloksiin.

\section{Luottamus instituutioihin}

Yleinen luottamus kansallisiin instituutioihin - eduskunta, poliitikot, poliittiset puolueet, oikeusjärjestelmä, poliisi - on ollut Suomessa vahvempaa kuin Etelä-Euroopassa, puhumattakaan itäisestä Keski-Euroopasta (Oksanen ym. 2020). Luottamuksella instituutioihin on tärkeä rooli pandemian kaltaisissa kriiseissä, sillä vahva luottamus helpottaa kriisin hallintaan tähtäävien toimenpiteiden toteuttamista ja edistää kansalaisten halua noudattaa toimintasuosituksia (Blair, Morse ja Tsai 2016; Devine ym. 2020; Väliverronen 2021). Näin luottamuksella voi olla tärkeä merkitys myös koronan kaltaisen epidemian hallinnassa ja kuolleisuuden rajoittamisessa (Oksanen ym. 2020). Pelkkä informaation jakaminen epidemiasta ja sen ehkäisystä ei siis riitä, jos luottamus instituutioihin on alhainen (Bangerter 2014; Blair, Morse ja Tsai 2016) tai jos väestö ei jaa käsitystä yhteisestä uhasta, jota on torjuttava yhteistyöllä (Bavel ym. 2020, 462).

Viranomaisten toimien ja suositusten hyväksymiseen liittyy halukkuus laittaa yksilölliset oikeudet, tarpeet ja halut hetkeksi taka-alalle, yhteisen hyvän vuoksi. Tämä on erityisen kiinnostava kysymys yksilön vapautta ja itsensä toteuttamista korostavissa yhteiskunnissa, kuten Suomi. 
Tällainen luottamus heijastaa usein vuosien ja vuosikymmenien aikana kertyneitä kokemuksia aikaisemmista epidemioista ja terveydenhuollon toimista niiden aikana (Larson ja Heymann 2010, 271) ja yleistä luottamusta kansallisiin instituutioihin (Oksanen ym. 2020). Näiden lisäksi on kiinnostavaa pohtia, näkyykö koronapandemian aikana niin sanottu lipun alle ryhmittyminen -ilmiö (rally around the flag). Termi viittaa intensiiviseen ja dramaattiseen kansainväliseen tapahtumaan, joka synnyttää kansallisessa kontekstissa ryhmittymisen kansallisten auktoriteettien ja johtajien ympärille. Tällaisia tapahtumia ovat tyypillisesti sotien dramaattiset käänteet sekä kansainvälisen politiikan akuutit kriisit tai neuvottelut (Mueller 1970, 21-22). Muellerin (emt.) mukaan kriisit näyttävät lisäävän esimerkiksi presidentin suosiota ainakin hetkellisesti. Myös koronaepidemian kohdalla on pohdittu, olisiko siitä seurannut tällainen ryhmittyminen kansallisten auktoriteettien ympärille (Devine ym. 2020; Jennings 2020). Bol ja kumppanit (2020) tutkivat seitsemän Euroopan maan tilannetta keväällä 2020 ja havaitsivat nimenomaan yhteiskunnan toimintojen laajan sulkemisen (lockdown), toisin kuin pienempien toimien kuten koulujen sulkemisen, lisänneen pääministeri- ja hallituspuolueiden kannatusta, tyytyväisyyttä demokratiaan ja luottamusta hallitukseen. He eivät kuitenkaan löytäneet rally around the flag -ilmiöitä siinä mielessä, että se olisi syntynyt globaalista terveyskriisistä itsestään, vaan nimenomaan lockdown-toimista.

Suomen ensimmäisissä koronakriisin aikaisissa mielipidekyselyissä ja median tulkinnoissa oli viitteitä sekä rally around the flag -ilmiöstä (esim. Haavisto 2020; Saarikoski 2020) että siitä, että kansalaiset olisivatkin erimielisiä hallituksen koronatoimien suhteen. Esimerkiksi maalis-huhtikuun vaihteessa tehdyssä EVA:n kyselyssä väitteen "Vaikka hallituksen toimet koronavirusepidemian torjumiseksi ovat poikkeuksellisen järeitä, annan niille täyden tukeni" hyväksyi $89 \%$ vastaajista ja vain $6 \%$ oli eri mieltä (Haavisto 2020). Kuitenkin samoihin aikoihin, maaliskuun 2020 lopulla, suomalaiset näyttivät Yleisradion teettämässä kyselyssä jakautuvan niihin, joiden mielestä hallituksen suositukset ja rajoitukset ovat olleet sopivia ja oikea-aikaisia (49\%), ja niihin, joiden mielestä hallituksen pitäisi pikemminkin asettaa tiukempia rajoituksia (46\%) (Yle 25.3.2020).

Toisaalta epidemioiden aikana voi myös syntyä epäluottamusta viranomaisia ja instituutioita kohtaan. Esimerkiksi Britannian hallituksen ja viranomaisten viivyttely ja epäonnistunut riskiviestintä hullun lehmän taudista 1990-luvulla johti epäluottamukseen hallitusta kohtaan (Lanska 1998, 173) ja laajemmin tiedeviestinnän käytäntöjen uudelleenarviointiin (House of Lords 2000; Väliverronen 2016, 134-135). Vuoden 2009 H1N1-pandemiaa (sikainfluenssa) koskeva tutkimus puolestaan osoitti, että Sveitsissä luottamus moniin instituutioihin, erityisesti Maailman terveysjärjestöön (WHO) ja lääketeollisuuteen, mutta myös Sveitsin hallitukseen laski (Bangerter ym. 2012). Suomessa sikainfluenssarokotuksen yhdistäminen lisääntyneeseen riskiin sairastua narkolepsiaan (THL 2011) ja viranomaisten viestinnän epäonnistuminen etenkin internetissä (Järvi 2010) saattoivat olla osasyinä sille, että sikainfluenssan jälkeen Suomessa on kiinnitetty huomioita kiinnittää huomioita rokotekriittisiin (Puumalainen ym. 2015). Toisaalta kyselytutkimusten ja rokotusrekisterin tietojen mukaan rokotusten hyväksyntä ja rokotuskattavuus on Suomessa edelleen maailman kärkeä (Väliverronen, Sivelä ja Nohynek 2020). 


\section{Tieteen ja asiantuntijoiden kyseenalaistaminen}

Kevään 2020 koronaepidemia ei ollut ensimmäinen kerta, kun Suomessa asiantuntijoihin kohdistettiin yhtäällä paljon toiveita ja luottamusta ja toisaalla ilmaistiin toistuvasti epäluottamusta ja epäluuloja. Institutionaalisten asiantuntijoiden tuottamaa tietoa kyseenalaistetaan nykyään yhä aggressiivisemmin, kuten esimerkiksi rokotteiden (esim. Kata 2012) ja ruokavalion (Jallinoja, Jauho ja Mäkelä 2016) kohdalla on saatu nähdä. Kansallisten terveysasiantuntijoiden kritiikistä onkin tullut tavallinen osa julkisuutta, ja esimerkiksi erilaiset ravintovalmentajat tarjoavat hanakasti omia, toisinaan virallisen terveysasiantuntemuksen kanssa poikkiteloin asettuvia suosituksiaan (Setälä ja Väliverronen 2014; Väliverronen 2016, 57).

Terveysriskejä koskevissa keskusteluissa on tapahtunut kaksi kehityskulkua: julkisuudessa esillä olevien asiantuntijoiden lukumäärä on kasvanut ja he edustavat aikaisempaa heterogeenisempää joukkoa ammattilaisia, päättäjiä, asiantuntijoita ja maallikoita (Jallinoja, Jauho ja Mäkelä 2016; Väliverronen ym. 2020). Esimerkiksi ravinnon rasvoista kiistelivät 1980-luvulla pääosin tiedeasiantuntijat ja eräät heitä kritisoivat lähialojen ammattilaiset, 2000-luvulla joukkoon liittyi aikaisempaa monipuolisempi joukko eri alojen ammattilaisia, järjestöjen edustajia ja maallikoita (Jallinoja, Jauho ja Mäkelä 2016). Tämä tuo keskusteluun myös jännitteitä, sillä eri taustoista tulevat asiantuntijat ja muut ammattilaiset arvioivat terveysriskejä ja varsinkin niiden hallintakeinoja eri tavoin. Maallikoille tämä saattaa näyttäytyä asiantuntijoiden hämmentävänä erimielisyytenä, sillä eri näkemysten taustoja ja merkityksiä on journalismissa vaikea tehdä ymmärrettäväksi. Esimerkiksi Italiassa huhtikuussa 2020 tehdyssä korona-aiheisessa kyselytutkimuksessa puolet vastaajista raportoi, että tieteelliset asiantuntijat ovat olleet erimielisiä ja aiheuttaneet hämmennystä (Bucchi ja Saracino 2020).

Millaisesta maaperästä versovat tieteeseen perustuvan asiantuntijuuden ja siihen nojaavien viranomaisten julkinen tarkkailu ja toistuva haastaminen, esimerkiksi terveyteen liittyvissä kysymyksissä?

Yhdysvalloissa on raportoitu tieteeseen kohdistuvan luottamuksen laskeneen erityisesti konservatiivien parissa ainakin 1980-luvulta alkaen (Gauchat 2012). Monet liittävät muutoksen nimenomaan jälkimoderniin yhteiskuntaan (esim. Giddens 1991; Beck 1994). Keskeisiä asiantuntijuuden kyseenalaistamisen taustalla olevia kehityskulkuja ovat koulutustason nousu, yksilöllistyminen ja mediamaiseman muutos (Väliverronen 2016, 49-54) sekä auktoriteettiuskon väheneminen ja liberaalien arvojen kasvu (Norris ja Inglehart 2019).

Edellä kuvatusta tieteen ja tutkijoiden uudentyyppisestä haastamisesta huolimatta kyselytutkimusten mukaan tieteen arvostus on viime vuosikymmeninä pysynyt vakaana länsimaissa (National Science Foundation 2018; Castell ym. 2014). Suomessa se on Tiedebarometrin (2019) mukaan pikemminkin noussut kuin laskenut. Luottamus tieteeseen, tutkimukseen ja tiedeyhteisöön kasvoi vuosien 2001 ja 2019 välillä 56 prosentista 71 prosenttiin (Hyvin suurta ja melko suurta luottamusta kokevien yhteenlaskettu osuus). Vastaava kasvu yliopistojen ja korkeakoulujen kohdalla oli 68 prosentista 77 prosenttiin (Tiedebarometri 2019, 46-47). Tämä luottamus näkyy myös joissakin erityisissä teemoissa kuten rokotuksissa (Wellcome Global Monitor 2018; Väliverronen, Sivelä \& Nohynek 2020). Samaan aikaan luottamus niin sanottuihin vaihtoehtohoitoihin, kuten homeopatiaan ja kansanparantajiin, laski (Tiedeba- 
rometri 2019, 91-94). Koronaepidemia muodostaa erityisen tieteeseen ja asiantuntijoihin nivoutuvan teeman, jota onkin kiinnostavaa tarkastella juuri luottamuksen näkökulmasta.

On huomattava, että luottamus tieteeseen ja asiantuntijoihin ei jakaudu väestöryhmissä tasaisesti. Lisäksi kansainvälisissä tiede- ja asiantuntijaluottamusta koskevissa kyselyissä on havaittu, että yleinen luottamus tieteeseen on eri asia kuin luottamus tieteen instituutioihin ja asiantuntijoihin yksittäisissä tieteeseen ja teknologiaan liittyvissä aiheissa (esim. Bauer, Allum ja Miller 2007; Väliverronen 2016, 171-175).

Vuoden 2019 Tiedebarometrissa oli ensimmäistä kertaa tarkasteltu tiedeasenteita suhteessa puoluekantaan, sosiodemografisten tekijöiden rinnalla. Mitä korkeampi koulutustaso, sitä enemmän suomalaiset luottivat tieteeseen. Koulutustason nousu saattaakin osaltaan selittää myönteisten arvioiden lisääntymistä tieteestä ja tutkijoista. Perussuomalaiset ja ei-äänestäneet luottivat vähiten tieteeseen yleensä ja vihreiden ja kokoomuksen kannattajat eniten. (Tiedebarometri 2019, 48-49.) Puoluekannan roolia tiedeasenteissa ovat tutkineet myös Arttu Saarinen kollegoineen (2018; 2020). Suomessa enemmistö kaikkien puolueiden kannattajista luotti vuonna 2017 yliopistoihin ja myös THL:ään luotti yli puolet kaikkien puolueiden kannattajista (Saarinen, Koivula ja Keipi 2018, 25). Perussuomalaiset luottivat yliopistoihin epätodennäköisemmin kuin keskustan, SPD:n ja vihreiden äänestäjät - silloinkin kun ikä, sukupuoli, koulutus ja asuinalue oli vakioitu (emt., 25). Vastaava yhteys havaittiin THL:n kohdalla, sillä erotuksella että nyt myös kokoomuksen kannattajat luottivat THL:ään enemmän kuin perussuomalaisten kannattajat (emt., 25).

Yhdysvalloissa arvokonservatiivisuus ja alhainen koulutus ennustavat epäluottamusta tieteeseen (McCright ym. 2013, 5-6). Korkeasti koulutetut ja miehet luottivat tieteeseen Yhdysvalloissa useammin kuin vähän koulutetut ja naiset (Gauchat 2012) ja korkeakoulututkinnon suorittaneet useammin kuin vähemmän koulutusta suorittaneet (Blank ja Shaw 2015). Liberaalit amerikkalaiset puolestaan luottivat tieteeseen useammin kuin konservatiivit (Gauchat 2012) ja demokraattien kannattajat luottivat tiedeperustaisiin ohjeisiin useammin kuin republikaanit ja riippumattomat (Blank ja Shaw 2015). Lisäksi konservatiivien ja liberaalien välinen ero luottamuksessa on kasvanut ja luottamuksen lasku on tapahtunut nimenomaan konservatiivien parissa, ei koko väestön keskuudessa (Gauchat 2012).

\section{Mediakentän muutokset}

Suomessa on varsin korkea luottamus uutismediaan (Reunanen 2020; Matikainen ym. 2020). Luottamus esimerkiksi Yle Uutisiin on kuitenkin ollut laskussa: vuonna 200794 prosenttia suomalaisista piti Yle Uutisia erittäin tai melko luotettavina kun vuonna 2019 tällaisia vastaajia oli 83 prosenttia (Matikainen ym. 2020, 21). Taustalla vaikuttaa mediamaiseman pirstoutuminen: uutismedian murros ja sosiaalisen median merkityksen kasvu, jotka molemmat rapauttavat perinteisten portinvartijoiden roolia (McIntyre 2018; Vihma ym. 2018), sekä valtamediaa kritisoivien vaihtoehto- tai vastamedioiden nousu (Noppari ja Hiltunen 2018). Russell Muirhead ja Nancy Rosenbaum (2019) väittävät vielä, ettei kyse ole edes pelkästään siitä, että keskeiset isot uutistalot ovat menettäneet portinvartijan roolinsa, vaan että portinvartijan tehtävä itsessään on lähes hävinnyt. Näin siis ammattimaisen uutismedian rooli tiedon valikoijana ja suodattajana tai tieteeseen nojautuvan asiantuntijuuden välittäjänä on heikentynyt. 
Medialla on tärkeä rooli asiantuntijuuden ja siihen liittyvän luottamuksen murroksessa. Media ei pelkästään välitä asiantuntijatietoa, vaan se myös luo käsityksiä siitä, kuka on asiantuntija ja millaista on asiantuntijatieto. Epidemia synnyttää helposti myös tilanteen, jossa erilaiset disinformaation ja misinformaation muodot leviävät epidemian tavoin verkon ja sosiaalisen median kaikkiruokaisessa kulttuurissa: infodemian (Cinelli ym. 2020). Yksi juonne tässä kehityskulussa on uudenlaisten salaliittoteorioiden muotoutuminen: ne haastavat tiede- ja asiantuntijapohjaiset tiedonhankintatavat ja keskeiset tiedeinstituutiot, kuten yliopistot ja tutkimuslaitokset, tilastointilaitokset ja ministeriöiden asiantuntijat (Muirhead ja Rosenblum 2019, 101-102). Tällaisia salaliittoteorioita on esitetty aikaisempien pandemioiden aikana. Niiden taustalla ei aina ole vain kansalaisten tietämättömyys vaan erilaisten intressiryhmien aktiivinen, epäluottamusta tietoisesti lisäävä toiminta (Bangerter 2014). Myös COVID19-rokote on liitetty erilaisiin salaliittoteorioihin, kuten väitteeseen, että rokote on Bill Gatesin ja Maailman terveysjärjestön salajuoni saada ihmiset ottamaan rokotus ja samalla "valvontasiru". COVID19:n on myös väitetty leviävän 5G-verkkojen kautta (Evans 2020) ja että se on hallitusten juoni saada inmiset tiukemmin valtaansa (BBC 30.8.2020). Asiantuntijuuden kyseenalaistaminen ja salaliittoteoriat näkyvät erityisen hyvin keskustelufoorumeilla ja muutenkin sosiaalisessa mediassa.

Tässä tutkimuksessa analysoimme edellä kuvattuja ilmiöitä koronaepidemian kohdalla Suomessa. Selvitämme ensin, miten suomalaiset luottivat kansallisiin instituutioihin koronakriisin käsittelyssä huhtikuussa ja kesäkuussa 2020. Vertailun vuoksi otamme mukaan myös Maailman terveysjärjestöä kohtaan tunnetun luottamuksen. Seuraavaksi analysoimme yksityiskohtaisemmin suomalaisten asenteita asiantuntijoihin, viranomaisiin ja sosiaalisen median vaikuttajiin koronakriisissä sekä yhteisölliseen ja yksilön vastuuseen liittyen. Kysymme, miten eri puolueiden kannattajat eroavat luottamuksessaan ja asenteiltaan. Analysoimme, miten sukupuoli, ikä, koulutus, asuinalue ja puoluekannatus ennustavat luottamusta eri toimijoihin.

Lopuksi pohdimme, miten voimme tulostemme valossa tulkita väitteitä tieteen ja asiantuntijoiden arvostuksen romahtamisesta. Pohdimme myös sitä, muuttaako koronakriisi suomalaisten suhtautumista kansallisiin instituutioihin.

\section{Aineisto ja menetelmät}

Aineistoina käytämme COVID19-pandemiaa koskevia väestökyselyjä. Ensimmäinen kysely toteutettiin 9.-14. huhtikuuta, pian valmiuslain ja koulujen sulkemisen asettamisen (16.3.2020), Suomen ensimmäisen COVID19-kuoleman (21.3.2020) ja Uudenmaan alueen rajojen sulkemisen (28.3.2020) jälkeen. Pian tämän jälkeen rajoituksia alettiin asteittain purkaa: Uudenmaan rajat avattiin (15.4.2020), koulut ja lastentarhat avattiin ja työmatkat Schengen-alueen sisällä sallittiin (14.5.2020). (Suomen koronatoimista ks. Tiirinki ym. 2020, 651-652.) Toinen kysely toteutettiin näiden muutosten jälkeen 5.-9. kesäkuuta, mutta hieman ennen kuin valmiuslaki päättyi (15.6.2020).

Aineiston keruun toteutti Kantar oy viikkovastaajapaneelinsa parissa (sähköinen lomake internetissä). Paneeli on edustava väestön suhteen (pl. Ahvenanmaa). Paneelin jäsenille lähetettiin yksi muistutusviesti kyselystä. Lomakkeen kysymykset koskivat median käyttöä, 
luottamusta eri medioihin, viranomaisiin, tieteeseen ja erilaisiin asiantuntijaryhmiin, sekä näkemyksiä Suomen koronatoimenpiteistä. Tähän tutkimukseen sisällytimme seuraavia muuttujia:

Luottamusta suhteessa kansallisen ja kansainvälisen tason toimijoihin mitattiin seuraavilla kysymyksillä: "Kuinka hyvin seuraavat tahot ovat mielestäsi onnistuneet koronakriisin käsittelyssä?", jonka jälkeen lueteltiin joukko toimijoita. Tässä tutkimuksessa analysoidaan seuraavia tahoja: Terveyden ja hyvinvoinnin laitos ( $\mathrm{THL}$ ), sosiaali- ja terveysministeriö (STM), Suomen hallitus, tasavallan presidentti ja Maailman terveysjärjestö (WHO). Kunkin toimijan kohdalla vastausvaihtoehdot olivat: Erittäin huonosti, Melko huonosti, Ei hyvin eikä huonosti, Melko hyvin, Erittäin hyvin ja En osaa sanoa.

Luottamusta mediaan mitattiin kysymyksellä "Kuinka luotettavana pidät seuraavia valtakunnallisia uutismedioita korona-asioiden uutisoinnissa". Tähän tutkimukseen valittiin mukaan Yle Uutiset ja MTV Uutiset'. Vastausvaihtoehdot olivat: Erittäin epäluotettava, Melko epäluotettava, Ei luotettava eikä epäluotettava, Melko luotettava, Erittäin luotettava ja En osaa sanoa.

Tiedettä, asiantuntijoita ja koronaan liittyviä tietoja koskevia näkemyksiä tiedusteltiin seuraavilla kysymyksillä: "Luotettavimpia asiantuntijoita koronaepidemian ennustamisessa ja hallinnassa ovat THL:n edustajat", "Luotettavimpia asiantuntijoita koronaepidemian ennustamisessa ja hoidossa ovat yliopistojen professorit ja tutkijat", "Tieteeseen ei voi luottaa, koska saman alan asiantuntijat voivat olla jostakin asiasta täysin eri mieltä", "Asiantuntijoiden erimielisyys ei välttämättä kerro tieteen epäluotettavuudesta, koska ristiriitaisetkin näkemykset kuuluvat tieteeseen", "Suomen hallitus perustaa toimensa vääriin laskelmiin", "Luotan viranomaisten ja asiantuntijoiden antamaan tietoon rokotteista ja rokottamisesta", "Korona ei ole seurauksiltaan tavallista flunssaa vaarallisempi", "Koronaviruksen vaarallisuutta on merkittävästi liioiteltu" ja "Koronaviruksen vaarallisuutta on vähätelty". Vastausvaihtoehdot olivat: Täysin eri mieltä, Jokseenkin eri mieltä, Jokseenkin samaa mieltä, Täysin samaa mieltä ja En osaa sanoa.

Sosiaalisen median vaikuttajista ja kokemusasiantuntijoista kysyttiin kahdella kysymyksellä: "Aktiiviset somevaikuttajat ovat osoittautuneet terveysviranomaisia paremmiksi asiantuntijoiksi koronaepidemian ennustamisessa" ja "Asiantuntijalla ei välttämättä tarvitse olla tieteellistä koulutusta, sillä käytännön kokemus ja näkemys on tärkeämpää". Molemmissa vastausvaihtoehdot olivat: Täysin eri mieltä, Jokseenkin eri mieltä, Jokseenkin samaa mieltä, Täysin samaa mieltä, En osaa sanoa.

Yhteisvastuuseen ja yksilöiden rooliin liittyviä näkemyksiä mitattiin seuraavilla kysymyksillä: "Koronakriisin hoidossa on rajoitettu liikaa yksilön vapauksia", "Viranomaisten ohjeista piittaamattomat yksilöt ovat merkittävä uhka suomalaisille", "Korona-aikana väestön terveyden suojelu on laitettava yksilöiden vapauden edelle", "Korona-aikana väestön terveyden suojelu on laitettava taloudellisten laskelmien edelle", "Olen pyrkinyt noudattamaan Suomen viranomaisten antamia neuvoja", "Olen saanut hyvin perustellut ohjeet viranomaisilta, miten 
toimia korona-pandemian aikana", "Koronarokotteen tulisi olla vapaaehtoinen" ja "Viranomaisten suosittelemista rokotteista kieltäytyminen on vastuutonta muita kohtaan". Vastausvaihtoehdot olivat: Täysin eri mieltä, Jokseenkin eri mieltä, Jokseenkin samaa mieltä, Täysin samaa mieltä ja En osaa sanoa.

Lisäksi vastaajapaneeliin kuuluvilta tiedustellaan vuosittain, kesällä, taustatekijöitä, joista tässä tutkimuksessa ovat mukana seuraavat (Taulukko 1): Sukupuoli (vastausvaihtoehdot mies, nainen), ikä (luokiteltuna 10-vuotisluokkiin), asuinalue (NUTS2-koodilla, luokiteltuna Helsinki-Uusimaa, Etelä-Suomi, Länsi-Suomi, Itä- ja Pohjois-Suomi), koulutus (kolmiluokkaisena seuraavasti 1. peruskoulu, kansakoulu, keskikoulu, ammattikoulu tai ylioppilas, 2. opistotaso, ammattikorkeakoulututkinto tai alempi korkeakoulututkinto ja 3. akateeminen koulutus) sekä puoluekanta (Kokoomus, Keskusta, Sosiaalidemokraattinen puolue SDP, Vihreät, Perussuomalaiset, Vasemmistoliitto, Ruotsalainen kansanpuolue RKP, Liike Nyt, Kristillisdemokraatit KD, Sininen tulevaisuus sekä muu puolue). Kantarin toimittamassa aineistossa RKP, Liike Nyt, KD ja Sininen tulevaisuus sekä muu puolue oli yhdistetty luokaksi "muu", sillä kussakin on alle 3 prosenttia vastaajia.

Vertailu Tilastokeskuksen tietoihin osoitti, että aineistossa naiset ja alle 30-vuotiaat olivat hieman aliedustettuina. Kyselyn koulutustietoja on hieman haasteellista verrata Tilastokeskuksen raportoimiin koulutustietoihin, mutta näyttää siltä, että vain perus-, kansa- tai keskikoulun suorittaneet olivat aliedustettuina kyselyssä ja akateemisen loppututkinnon suorittaneet puolestaan yliedustettuina. Asuinalueen suhteen aineisto on varsin edustava. Puoluekannatuksen vertaaminen edellisten eduskuntavaalien tuloksiin on hankalaa jo siksi, että kyselyssä on mahdollista valita "en osaa sanoa", "en aio äänestää ja "en halua sanoa" -vaihtoehdot, joita valitsi yhteensä 29,2 prosenttia koronakyselyiden vastaajista. Emme voi varmuudella sanoa, oliko kyselyaineisto edustava puoluekannan suhteen.

Tarkastelemme ensin muuttujien suoria jakaumia kahtena mittausajankohtana. Mittausajankohtien välisiä eroja testasimme Khiin neliötestillä. Seuraavaksi tarkastelimme ristiintaulukoimalla luottamus- ja asennemuuttujien yhteyttä puoluekantaan. Lopuksi valitsimme binaariseen logistiseen regressioanalyysin muuttujia, joita selitimme sukupuolella, iällä, asuinalueella, koulutuksella, puoluekannalla sekä mittausajankohdalla. Koska asuinalue ei osoittautunut tilastollisesti merkitseväksi selittäjäksi malleissa, jätimme sen lopullisista analyyseistä pois. 
Taulukko 1. Vastaajien sukupuoli, ikä, asuinalue, koulutus ja arvio puolueesta, jota äänestäisi $(n=2265)$, vertailu Tilastokeskuksen tietoihin ja vuoden 2019 eduskuntavaalien tulokseen.

\begin{tabular}{|c|c|c|c|}
\hline & Huhtikuu ( $n=1138$ ) & Kesäkuu (n=1127) & Väestötietoja \\
\hline Sukupuoli & & & Tilastokeskus 2020 \# \\
\hline Nainen & 48,2 & 47,7 & 51,7 \\
\hline Mies & 51,8 & 52,3 & 48,3 \\
\hline \multicolumn{4}{|l|}{ Ikä } \\
\hline Min - Max & 18 - 90 vuotta & 15 - 90 vuotta & Tilastokeskus $2020 \S$ \\
\hline Alle $30 \mathrm{v}$. & 15,6 & 13,8 & 20,9 \\
\hline $30-39 \mathrm{v}$ & 16,6 & 15,4 & 15,5 \\
\hline $40-49 v$ & 14,7 & 14,7 & 14,4 \\
\hline $50-59 \mathrm{v}$. & 17,6 & 17,8 & 15,7 \\
\hline $60-69 \mathrm{v}$. & 17,7 & 19,1 & 15,5 \\
\hline 70 v. + & 17,7 & 19,2 & 18 \\
\hline Asuinalue & & & Tilastokeskus $2020 \#$ \\
\hline Helsinki-Uusimaa & 33,4 & 33,9 & 30,8 \\
\hline Etelä-Suomi & 19,8 & 20,6 & 20,88 \\
\hline Länsi-Suomi & 24,3 & 22,8 & 25,1 \\
\hline Pohjois/Itä-Suomi & 22,5 & 22,7 & 23,22 \\
\hline Koulutus & & & Tilastokeskus 2018 \# \\
\hline Perus-, kansa- tai keskikoulu & 8,3 & 9,1 & 26,7 \\
\hline Ammatillinen perustutkinto, ammattikoulu & 21,2 & 20,3 & Toinen aste: 41,6 \\
\hline Ylioppilas & 12 & 10,8 & (sis. edelliseen) \\
\hline Opistoasteen ammatillinen tutkinto & 16,4 & 17,3 & Alin korkea-aste 9,3 \\
\hline $\begin{array}{l}\text { Ylempi opistoasteen tutkinto, ammatti- } \\
\text { korkeakoulututkinto, alempi yliopiston tai } \\
\text { korkeakoulun akateeminen tutkinto }\end{array}$ & 21,4 & 21,2 & 11,7 \\
\hline $\begin{array}{l}\text { Yliopiston ja korkeakoulun ylempi } \\
\text { akateeminen tutkinto tai korkeampi }\end{array}$ & 20,1 & 20,8 & 10,7 \\
\hline Muu & 0,6 & 0,5 & \\
\hline Äänestäisi nyt & & & Puolueiden kannatus* \\
\hline Kokoomus & 14,1 & 13,8 & 17 \\
\hline SDP & 10,2 & 10,4 & 17,7 \\
\hline Keskusta & 7,6 & 7,7 & 13,8 \\
\hline Vihreät & 13,7 & 12,2 & 11,5 \\
\hline Perussuomalaiset & 11,9 & 12,2 & 17,5 \\
\hline Vasemmistoliitto & 7,1 & 7,1 & 8,2 \\
\hline Muu & 6,4 & 6 & 14,3 \\
\hline Ei äänestäisi & 3,2 & 3,9 & \\
\hline Ei osaa sanoa & 12,7 & 12,4 & \\
\hline Ei halua sanoa & 13,3 & 14,3 & \\
\hline
\end{tabular}

*Eduskuntavaalit 2019, https://vaalit.yle.fi/ev2019/fi/parties

\# http://pxnet2.stat.fi/PXWeb/pxweb/fi/StatFin/

§ Laskettu 15-89-vuotiaasta väestöstä, toukokuu 2020 


\section{Tulokset}

Tarkastelimme ensin vastaajien käsityksiä eräiden kansallisen tason toimijoiden ja Maailman terveysjärjestön (WHO) onnistumisesta koronakriisin käsittelyssä (Kuvio 1). Sekä huhtikuun että kesäkuun 2020 kyselyissä enemmistö vastaajista arvioi, että THL, STM, Suomen hallitus ja tasavallan presidentti olivat onnistuneet koronakriisin käsittelyssä melko hyvin tai hyvin. Suomen hallitus ja tasavallan presidentti saivat muita toimijoita useammin "erittäin hyvin onnistunut" arvion. On kiinnostavaa, että erityisesti tasavallan presidenttiin tyytymättömien osuus oli erittäin pieni - vaikka presidentin rooli epidemian torjuntatoimissa on huomattavasti pienempi kuin hallituksen tai THL:n. WHO pärjäsi arvioissa jonkin verran huonommin kuin suomalaiset toimijat, mutta vain alle viidennes arvioi sen toiminnan huonoksi.

Käsitykset muuttuivat huhtikuun ja kesäkuun välillä siten, että STM:n $(p=0,012)$, Suomen hallituksen $(p=0,011)$ ja tasavallan presidentin $(p=0,20)$ toiminnan erittäin hyväksi arvioineiden osuudet laskivat hieman.

Myös Yle Uutisia arvioitiin molemmissa mittauksissa varsin myönteisesti: enemmistö piti molemmissa mittauksissa Yle Uutisten korona-aiheista käsittelyä melko tai erittäin luotettavana (Kuvio 2). Erot mittausten välillä eivät olleet tilastollisesti merkitseviä. Verrattuna Yle Uutisiin, MTV Uutisia pidettiin tyypillisemmin melko luotettavina, vain noin joka kymmenes piti niitä melko tai erittäin epäluotettavina.

Luottamus eri tahoihin korreloi vahvasti keskenään (huhtikuun ja kesäkuun aineistoa on analysoitu yhdessä). Luottamus oli erityisen korkeaa THL:ää ja STM:ää kohtaan tunnetun luottamuksen välillä $(0,685, \mathrm{p}<0,000)$, Yle Uutisia ja MTV Uutisia kohtaan tunnetun luottamuksen välillä $(0,501, \mathrm{p}<0,000)$ ja Suomen hallitusta ja tasavallan presidenttiä koskevan luottamuksen välillä $(0,583, p<0,000)$. Kun tarkastellaan mediaa kohtaan tunnetun luottamuksen korrelaatiota instituutioita kohtaan tunnetun luottamuksen kanssa havaitaan, että luottamus Yle Uutisiin korreloi voimakkaimmin Suomen hallitusta kohtaan tunnetun luottamuksen kanssa $(0,445, p<0,000)$, kun taas MTV Uutisten kohdalla tällainen yhteys oli heikompaa; korkein se oli THL:n kohdalla (o,301, p<0,000). 
Kuvio 1. Arviot THL:n, STM:n Suomen hallituksen, tasavallan presidentin ja Maailman terveysjärjestön (WHO) onnistumisesta koronakriisin käsittelyssä, huhtikuun $(n=1138)$ ja kesäkuun $2020 \quad(n=1127)$ kyselyt.

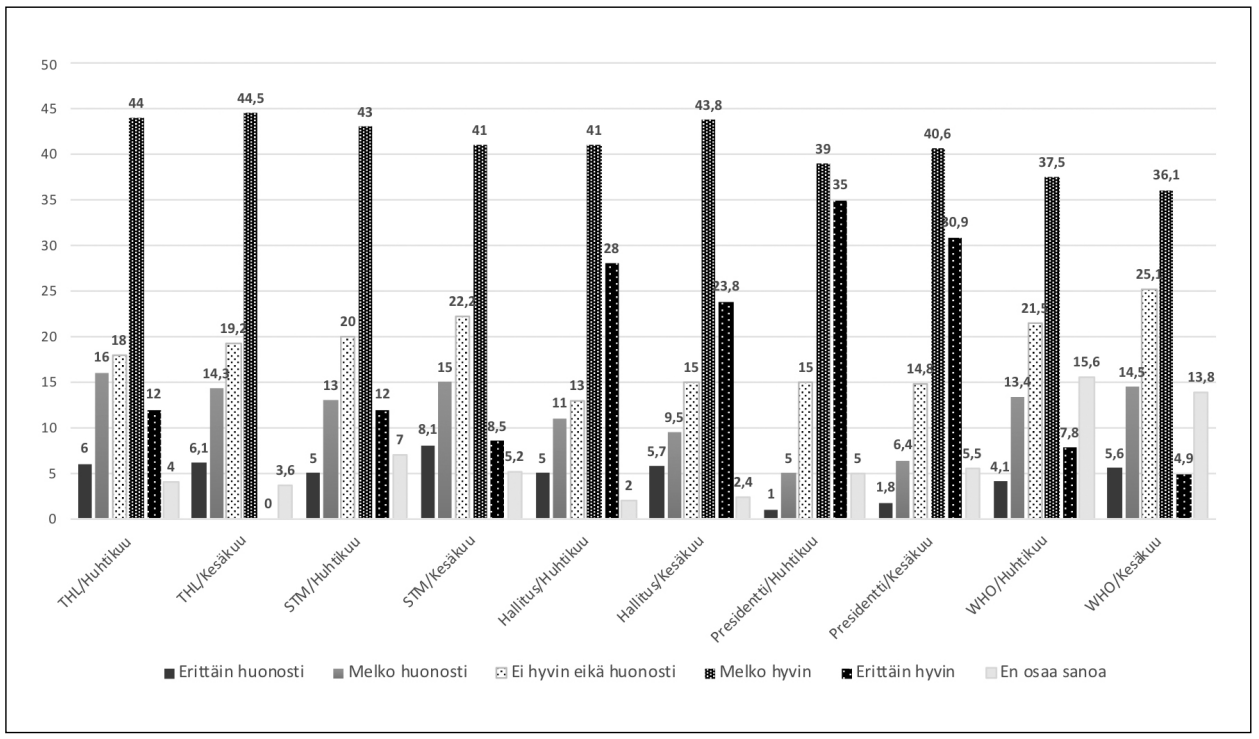

Kuvio 2. Luottamuksesta Yle Uutisiin ja MTV Uutisiin korona-asioista uutisoinnissa, huhtikuun $(n=1138)$ ja kesäkuun $2020(n=1127)$ kyselyt.

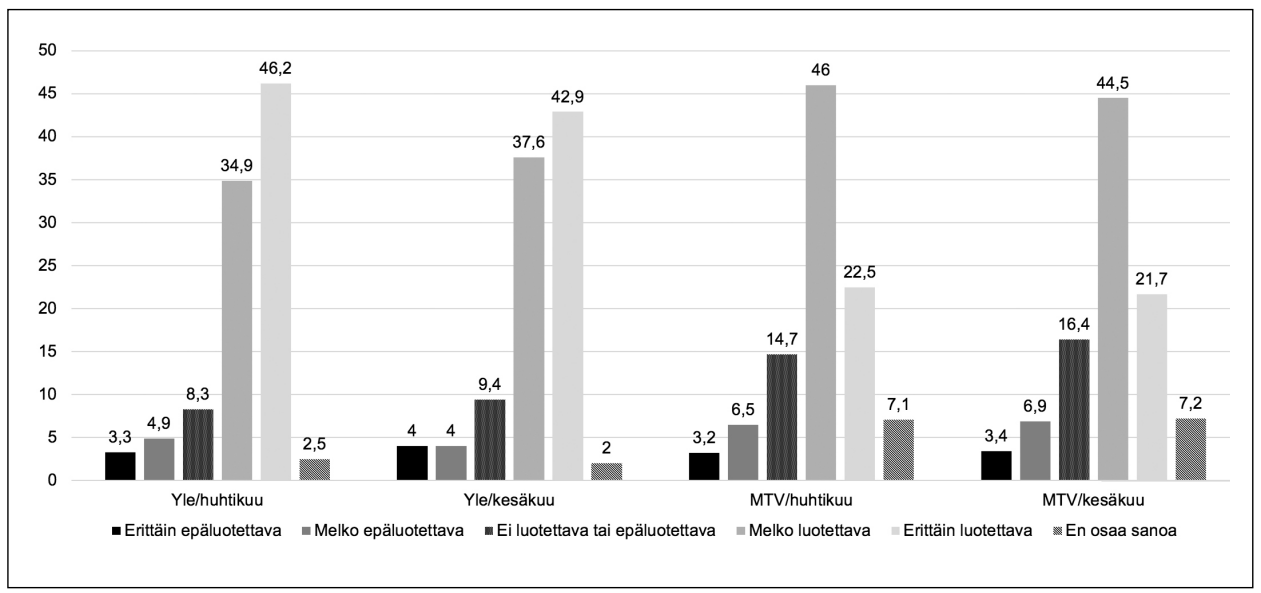

Seuraavaksi tarkastelemme vastaajien näkemyksiä koskien asiantuntijoita, viranomaisia, sosiaalisen median vaikuttajia sekä suhtautumista yhteisvastuuseen ja yksilön rooliin koronakriisin ratkaisemisessa (Taulukko 2). Myös tässä tarkastelussa vastaajista enemmistö luotti johdonmukaisesti THL:n ja yliopistojen asiantuntijoihin, viranomaisten jakamaan tietoon ja hallituksen käyttämiin laskelmiin korona-asiassa. Enemmistö myös arvioi, että asiantuntijoiden erimielisyys ei kerro tieteen epäluotettavuudesta. Huomattavasti harvempi 
luotti kokemuspohjaiseen asiantuntijuuteen tai somevaikuttajiin: Lähes kolmannes vastaajista uskoi, että asiantuntijalla ei välttämättä tarvitse olla tieteellistä koulutusta, sillä käytännön kokemus riittää. Joka kymmenes arvioi somevaikuttajat terveysviranomaisia paremmiksi asiantuntijoiksi koronaepidemian ennustamisessa.

Taulukko 2. Vastaajien suhtautuminen asiantuntijoihin, tieteeseen, viranomaisiin, sosiaalisen median vaikuttajiin, yhteisölliseen ja yksilön vastuuseen, korona-aikana, huhtikuu $(n=1138)$ ja kesäkuu 2020 ( $n=1127)$, täysin ja jossain määrin samaa mieltä olevien osuudet.

\begin{tabular}{|c|c|c|c|}
\hline & $\begin{array}{l}\text { Huhtik. } \\
(n=1138)\end{array}$ & $\begin{array}{l}\text { Kesäk. } \\
(\mathrm{n}=1127)\end{array}$ & $\begin{array}{l}\text { Muutoksen } \\
\text { tilastollinen } \\
\text { merkitsevyys§} \\
\end{array}$ \\
\hline \multicolumn{4}{|l|}{ ASIANTUNTIJOIHIN, VIRANOMAISIIN JA KORONATIETOON SUHTAUTUMINEN } \\
\hline $\begin{array}{l}\text { Asiantuntijoiden erimielisyys ei välttämättä kerro tieteen epäluotettavuudesta, } \\
\text { koska ristiriitaisetkin näkemykset kuuluvat tieteeseen + }\end{array}$ & 81,5 & 83,3 & ns. \\
\hline $\begin{array}{l}\text { Luotan viranomaisten ja asiantuntijoiden antamaan tietoon rokotteista ja } \\
\text { rokottamisesta }\end{array}$ & -- & 79,7 & -- \\
\hline $\begin{array}{l}\text { Luotettavimpia asiantuntijoita koronaepidemian ennustamisessa ja hoidossa } \\
\text { ovat yliopistojen professorit ja tutkijat }+\end{array}$ & 72 & 72 & ns. \\
\hline $\begin{array}{l}\text { Luotettavimpia asiantuntijoita koronaepidemian ennustamisessa ja hallinnassa } \\
\text { ovat THL:n edustajat + }\end{array}$ & 69 & 65 & ns. \\
\hline $\begin{array}{l}\text { Tieteeseen ei voi luottaa, koska saman alan asiantuntijat voivat olla jostakin } \\
\text { asiasta täysin eri mieltä + }\end{array}$ & 29,9 & 30,1 & ns. \\
\hline Suomen hallitus perustaa toimensa vääriin laskelmiin korona-asiassa\# & 17,2 & 20,4 & ns. \\
\hline \multicolumn{4}{|l|}{ SUHTAUTUMINEN SOMEVAIKUTTAJIIN JA KOKEMUSASIANTUNTIJOIHIN } \\
\hline $\begin{array}{l}\text { Asiantuntijalla ei välttämättä tarvitse olla tieteellistä koulutusta, sillä käytän- } \\
\text { nön kokemus riittää }+\end{array}$ & 30,9 & 28,5 & ns. \\
\hline $\begin{array}{l}\text { Aktiiviset somevaikuttajat ovat osoittautuneet terveysviranomaisia parem- } \\
\text { miksi asiantuntijoiksi koronaepidemian ennustamisessa }+\end{array}$ & 11,1 & 11,6 & ns. \\
\hline \multicolumn{4}{|l|}{ KORONOVIRUKSEN VAKAVUUTEEN LIITTYYÄT ARVIOT } \\
\hline Koronaviruksen vaarallisuutta on vähätelty & 35,6 & 27,3 & $\star \star \star *$ \\
\hline Koronaviruksen vaarallisuutta on merkittävästi liioiteltu & 17,8 & 23,6 & *** \\
\hline Koronavirus ei ole seurauksiltaan tavallista flunssaa vaarallisempi & 12,3 & 13,1 & ns. \\
\hline \multicolumn{4}{|l|}{ SUHTAUTUMINEN YHTEISVASTUUSEEN JA YKSILÖIDEN ROOLIIN } \\
\hline Olen pyrkinyt noudattamaan Suomen viranomaisten antamia neuvoja \# & 92,6 & 92 & ns. \\
\hline $\begin{array}{l}\text { Korona-aikana väestön terveyden suojelu on laitettava yksilöiden vapauden } \\
\text { edelle\# }\end{array}$ & 85,4 & 78,2 & *** \\
\hline $\begin{array}{l}\text { Korona-aikana väestön terveyden suojelu on laitettava taloudellisten } \\
\text { laskelmien edelle \# }\end{array}$ & 85,2 & 80,7 & * \\
\hline $\begin{array}{l}\text { Viranomaisten ohjeista piittaamattomat yksilöt ovat merkittävä uhka } \\
\text { suomalaisille\# }\end{array}$ & 84 & 77,6 & *** \\
\hline $\begin{array}{l}\text { Olen saanut hyvin perustellut ohjeet viranomaisilta, miten toimia korona- } \\
\text { pandemian aikana \# }\end{array}$ & 81,9 & 77,9 & * \\
\hline $\begin{array}{l}\text { Viranomaisten suosittelemista rokotteista kieltäytyminen on vastuutonta } \\
\text { muita kohtaan }\end{array}$ & -- & 70,5 & -- \\
\hline Koronarokotteen tulisi olla vapaaehtoinen & -- & 67,4 & -- \\
\hline Koronakriisin hoidossa on rajoitettu liikaa yksilön vapauksia \# & 12,1 & 18,7 & *** \\
\hline
\end{tabular}

I" * ${ }^{*} 0,05 ;{ }^{* *}<0,01 ; * * *<0,001$

\#Kysymykset oli kehystetty johdannolla "Vielä muutama väittämä koronakriisin hallinnasta"

§ Kysymykset oli kehystetty johdannolla "Sitten väittämiä koronaepidemian leviämisen hallinnasta"

+Kysymykset oli kehystetty johdannolla "Seuraavaksi koronaepidemiaan liittyviä kysymyksiä"

Kysymykset kehystetty johdannolla "Kysymyksiä koronarokotuksesta" 
Keväällä 2020 suomalaiset olivat pikemminkin taipuvaisia arvioimaan, että koronan vaarallisuutta on vähätelty, kuin että sitä oli liioiteltu. Koronan vähättelyyn uskoi reilu kolmannes huhtikuussa ja reilu neljännes kesäkuussa.

Yhteisvastuuta ja yksilön velvollisuuksia koskevat väittämät osoittivat, että enemmistö vastaajista pyrki noudattamaan viranomaisohjeita eikä kokenut, että yksilöiden vapauksia on rajoitettu liikaa. Samoin enemmistö katsoi, että terveyden suojelu on asetettava yksilöiden vapauden ja taloudellisten näkökohtien edelle. Koronarokotuksista kieltäytyjiä enemmistö piti vastuuttomina, mutta samalla enemmistö uskoi, että koronarokotusten tulisi olla vapaaehtoisia.

Joidenkin muuttujien kohdalla tapahtui tilastollisesti merkitseviä muutoksia huhtikuun ja kesäkuun 2020 välillä: Koronaviruksen vaarallisuuden liioitteluun uskovien osuus lisääntyi ja vaarallisuuden vähättelyyn uskovien puolestaan väheni. Huoli yksilöiden vapauksien rajoittamisesta lisääntyi ja viranomaisten ohjeista piittaamattomista ihmisistä väheni. Terveyden suojelua ei enää yhtä usein asetettu yksilön vapauksien ja taloudellisten laskelmien edelle.

Seuraavaksi tarkastelemme puoluekannan, sukupuolen, iän ja koulutuksen yhteyttä luottamukseen ja näkemyksiin. Tarkastelemme ensin eräiden muuttujien yhteyttä puoluekantaan kesäkuun mittauksessa, sillä osa kysymyksistä kysyttiin vain silloin (Kuvio 3, Kuvio 4).

Tarkastelu osoittaa, että perussuomalaisten kannattajat luottivat muiden puolueiden kannattajia harvemmin Suomen hallitukseen, hallituksen käyttämiin koronalaskelmiin, viranomaisiin ja THL:ään (Kuvio 3). Samalla he suhtautuivat muiden puolueiden kannattajia myönteisemmin somevaikuttajiin ja arvioivat, että koronaviruksen vaarallisuutta on merkittävästi liioiteltu. Oppositiopuolue kokoomuksen kannattajat olivat lähempänä hallituspuolueita kuin perussuomalaisten kannattajia.

Kuvioon 4 on koottu yhteisvastuuseen ja yksilöiden toimintaan liittyviä tuloksia kesäkuussa 2020. Ensiksi on syytä huomata eri puolueiden kannattajien välinen yksimielisyys joissain teemoissa: Vähintään kolme neljäsosaa kaikkien puolueiden kannattajista piti viranomaisten ohjeista piittaamattomia yksilöitä uhkana. Vastaava yhteisymmärrys oli myös siitä, että korona-aikana terveyden suojelu on laitettava yksilöiden vapauden edelle. Kuitenkin yksilönvapauksien rajoittamisesta korona-aikana olivat tyypillisimmin huolissaan perussuomalaisten, harvimmin vasemmistoliiton ja vihreiden kannattajat. Koronarokotusten vapaaehtoisuutta arvostivat eniten SDP:n, perussuomalaisten ja keskustan kannattajat. Koronarokotuksista kieltäytymistä pitivät vastuuttomana useiten kokoomuksen ja SDP:n kannattajat, harvimmin perussuomalaisten kannattajat. 
Kuvio 3. Asenteet Suomen hallitukseen, asiantuntijoihin, viranomaisiin, sosiaalisen median vaikuttajiin ja kokemuspohjaiseen asiantuntijuuteen, eri puolueiden kannattajien parissa, täysin tai jokseenkin saama mieltä olevien osuudet, kesäkuu 2020, $(n=1127)$.

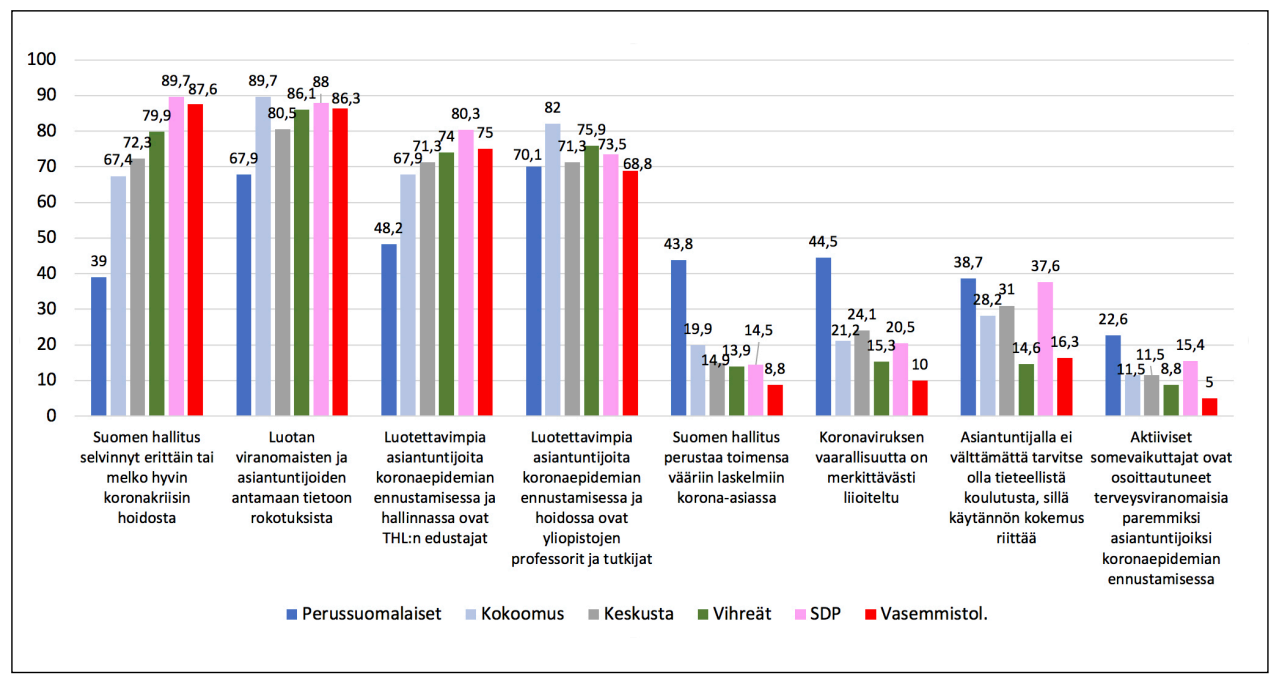

Kuvio 4. Asenteet yksilön vastuuseen ja vapauteen sekä koronarokotukseen, eri puolueiden kannattajien parissa, kesäkuu 2020, täysin tai jokseenkin saama mieltä olevien osuudet $(n=1127)$.

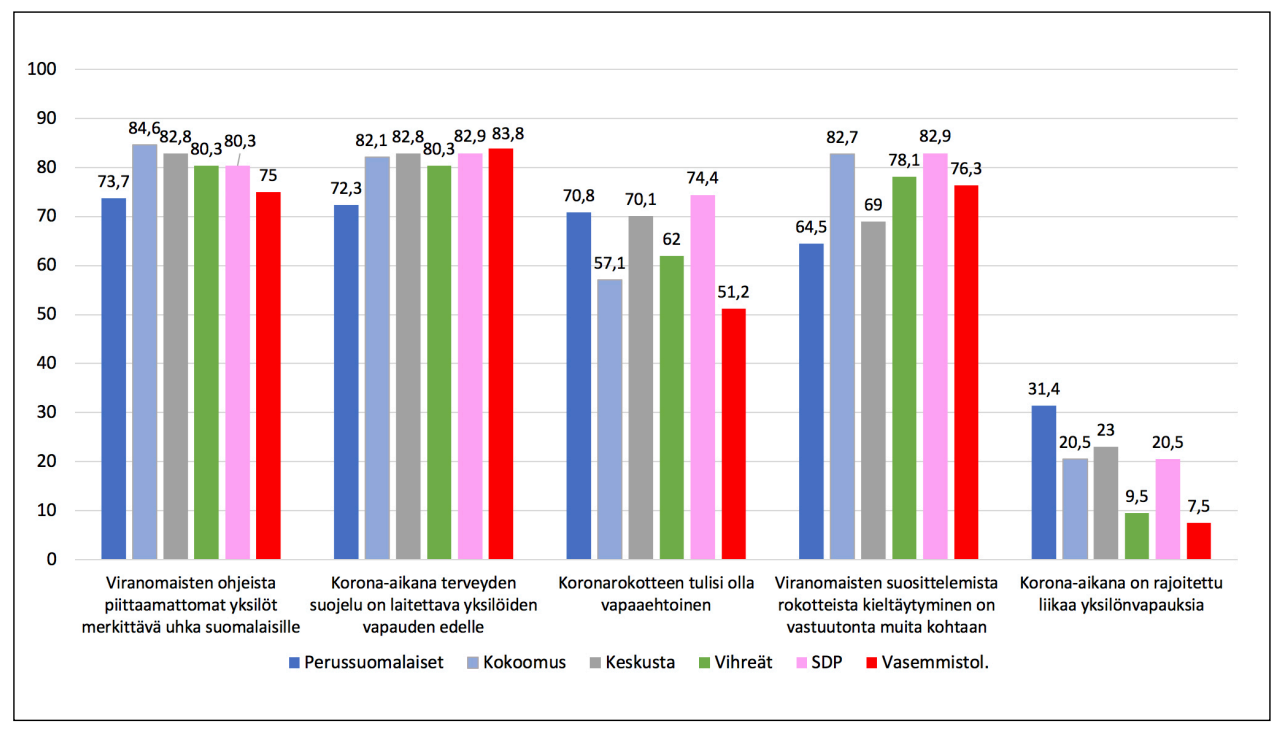

Seuraavaksi otimme mukaan tarkempaan analyysiin osan muuttujista (Taulukko 3, ja vain tekstissä esitettävät tulokset, joista esitämme vetosuhteen (OR) ja 95\% luottamusvälin). Valitsimme perussuomalaisten kannattajat referenssipuolueeksi, koska kuvioiden 3 ja 4 perusteella nämä vastaajat erottuivat johdonmukaisimmin muiden puolueiden kannattajista. 
Taulukko 3. Suhtautuminen THL:ään, Yle Uutisiin ja somevaikuttajiin, koronapandemian kohdalla. Todennäköisyys suhteessa sosiodemografisiin tekijöihin, puoluekantaan ja kyselyaikaan, huhtikuu ja kesäkuu 2020 (OR=Odds Ratio; $\mathrm{Cl}=$ Confidence Interval) \#

\begin{tabular}{|c|c|c|c|c|c|c|c|}
\hline & & \multicolumn{2}{|c|}{$\begin{array}{l}\text { THL selvinnyt erittäin } \\
\text { tai melko hyvin korona- } \\
\text { kriisin käsittelyssä }\end{array}$} & \multicolumn{2}{|c|}{$\begin{array}{l}\text { Yle Uutiset erittäin } \\
\text { tai melko luotettava } \\
\text { korona-asioiden } \\
\text { uutisoinnissa }\end{array}$} & \multicolumn{2}{|c|}{$\begin{array}{l}\text { Aktiiviset somevaikutta- } \\
\text { jat terveysviranomasia } \\
\text { parempia koronan ennus- } \\
\text { tamisessa (täysin/melko } \\
\text { samaa mieltä) }\end{array}$} \\
\hline & & \multicolumn{2}{|c|}{ Nagelkerke R2 $=0.078$} & \multicolumn{2}{|c|}{ Nagelkerke R2 $=0.108$} & \multicolumn{2}{|c|}{ Nagelkerke R2 =0.080 } \\
\hline & $n=2265$ & & & & & & \\
\hline & & OR, sig & $(95 \% \mathrm{Cl})$ & OR, sig & $(95 \% \mathrm{Cl})$ & OR, sig & $(95 \% \mathrm{Cl})$ \\
\hline \multicolumn{8}{|l|}{ Sukupuoli } \\
\hline Nainen & 1087 & 1 & & 1 & & 1 & \\
\hline Mies & 1178 & $0,686^{* * *}$ & $(0,575-0.817)$ & $0,503^{* \star *}$ & $(0,400-633)$ & $1,750^{\star * *}$ & $(1,319-2,323)$ \\
\hline \multicolumn{8}{|l|}{ Ikä } \\
\hline Alle $30 \mathrm{v}$. & 332 & 1 & & 1 & & 1 & \\
\hline 30-39 v. & 363 & 0,76 & $(0,555-1,040)$ & 0,776 & $(0,538-1,120)$ & 0,664 & $(0,430-1,023)$ \\
\hline $40-49 \mathrm{v}$ & 333 & 0,98 & $(0,708-1,357)$ & 0,968 & $(0,659-1,422)$ & $0,617^{*}$ & $(0,393-0,968)$ \\
\hline $50-59 \mathrm{v}$ & 401 & 0,928 & $(0,679-1,267)$ & 1.402 & $(0,946-2,078)$ & $0,454^{\star * *}$ & $(0,288-0,717)$ \\
\hline $60-69 \mathrm{v}$ & 417 & 1,197 & $(0,879-1,630)$ & 1,362 & $(0,926-2,003)$ & $0,377^{* \star *}$ & $(0,234-0,609)$ \\
\hline $70+v$ & 419 & 0,953 & $(0,700-1,298)$ & $1,734^{\star *}$ & $(1,153-2,608)$ & $0,500 * *$ & $(0,319-0,783)$ \\
\hline \multicolumn{8}{|l|}{ Koulutus } \\
\hline $\begin{array}{l}\text { Peruskoulu/ammattik./ } \\
\text { ylioppilas }\end{array}$ & 925 & 1 & & 1 & & 1 & \\
\hline AMK/alempi korkeak. & 864 & 1,134 & $(0,930-1,382)$ & $1,654^{* * *}$ & $(1,287-2,127)$ & $0,673^{\star *}$ & $(0,497-0,914)$ \\
\hline Akateeminen & 463 & 1,18 & $(0,927-1,501)$ & $1,770^{\star \star \star}$ & $(1,292-2,424)$ & $0,536^{\star *}$ & $(0,356-0,806)$ \\
\hline \multicolumn{8}{|l|}{ Puoluekannatus } \\
\hline Perussuomalaiset & 272 & 1 & & 1 & & 1 & \\
\hline Kokoomus & 316 & $2,031^{\star \star \star}$ & $(1,437-2,872)$ & $2,337^{\star \star *}$ & $(1,512-3,614)$ & $0,578^{*}$ & $(0,358-0,933)$ \\
\hline Keskusta & 173 & $2,859^{\star * *}$ & $(1,904-4,293)$ & $1,724^{*}$ & $(1,066-2,787)$ & 0,61 & $(0,353-1,055)$ \\
\hline Vihreät & 293 & $2,758^{* * *}$ & $(1,940-3,921)$ & $2,427^{\star * *}$ & $(1,585-3,715)$ & $0,345^{\star \star \star}$ & $(0,205-0,579)$ \\
\hline SDP & 233 & $5,004^{* * *}$ & $(3,375-7,420)$ & $4,867^{\star \star \star}$ & $(2.823-8,390)$ & $0,446^{\star \star}$ & $(0,264-0,753)$ \\
\hline Vasemmistoliitto & 161 & $3,103^{* * *}$ & $(2,041-4,718)$ & $2,139^{*}$ & $(1,285-3,562)$ & $0,286^{* * *}$ & $(0,141-0,582)$ \\
\hline Muu/eos/ei äänestä & 817 & $1,650^{* * *}$ & $(1,235-2,205)$ & $1,400^{*}$ & $(1,022-1,918)$ & $0,430^{\star \star *}$ & $(0,295-0,627)$ \\
\hline \multicolumn{8}{|l|}{ Kysely } \\
\hline Huhtikuu & 1138 & 1 & & 1 & & 1 & \\
\hline Kesäkuu & 1127 & 1,048 & $(0,881-1,242)$ & 0,944 & $(0,758-1,174)$ & 1,082 & $(0,828-1,414)$ \\
\hline
\end{tabular}

${ }^{*} p<0.05,{ }^{* *} p<0.01,{ }^{* * *} p<0.001$

\# Kaikkiin malleihin on sisällytetty seuraavat muuttujat samaan aikaan: sukupuoli, ikä, koulutus, puoluekannatus ja kyselyn ajankohta.

Sosiodemografisen taustan ja puoluekannatuksen yhteisvaikutuksen huomioiva regressioanalyysi osoitti, että THL:n toimintaan koronakriisin käsittelyssä myönteisimmin suhtautuivat naiset ja puolueista kielteisimmin perussuomalaisten kannattajat. Kaikkein myönteisin suhtautuminen THL:ään oli SPD:n kannattajien parissa. Yle Uutisten kohdalla naiset, yli 70-vuotiaat ja vähintään opistotason tutkinnon tai alemman korkeakoulututkinnon suorittaneet olivat luottavaisimpia. Puolueista perussuomalaisten kannattajat olivat kriittisimpiä. Kaikkein luottavaisimpia olivat SPD:n kannattajat. On syytä nostaa esille, että puolueiden kannattajien 
välisistä eroista huolimatta perussuomalaistenkin kannattajista 64,4 prosenttia luotti Yle Uutisiin huhtikuussa ja 67,9 prosenttia kesäkuussa. Huhtikuussa 34,1 prosenttia ja kesäkuussa 39,4 prosenttia heistä arvioi, että THL on selvinnyt hyvin koronakriisin käsittelyssä.

Analysoimme vielä suhtautumisen MTV Uutisiin (tulos ei sisälly taulukoihin), jonka kohdalla tyytymättömimpiä olivat miehet $\left(\mathrm{OR}=0,482^{\star \star *}, 95 \% \mathrm{Cl} 0,398-0,582\right)$ ja akateemisen tutkinnon suorittaneet $\left(\mathrm{OR}=0,719^{\star *}, 95 \% \mathrm{Cl} 0,560\right.$ - 0,923), tyytyväisimpiä yli 40-vuotiaiden ikäryhmät (verrattuna alle 30-vuotiaisiin). Kokoomuksen kannattajat $\left(\mathrm{OR}=2,104^{\star \star \star}, 95 \% \mathrm{Cl}\right.$ 1,428 - 3,100) pitivät MTV Uutisia luotettavina todennäköisemmin kuin perussuomalaisten kannattajat, ja vasemmistoliiton kannattajat puolestaan luottivat MTV Uutisiin epätodennäköisemmin $\left(\mathrm{OR}=0,555^{\star *}, 95 \% \mathrm{Cl} 0,367-0,839\right)$ kuin perussuomalaisten kannattajat. Miehet pitivät naisia useammin aktiivisia somevaikuttajia viranomaisia parempina koronan ennustamisessa (OR=1,750***, 95\% Cl 1,319-2,323). Myös alle 30-vuotiaat vastaajat (verrattuna vähintään 40-vuotiaisiin vastaajiin) ja alimpaan koulutusryhmään kuuluvat olivat somevaikuttajien kannalla. Keskustaa lukuunottamatta kaikki puolueet luottivat harvemmin somevaikuttajiin kuin perussuomalaisten kannattajat. Vasemmistoliiton ( $\mathrm{OR}=0,286,95 \% \mathrm{Cl} 0,141-0,582)$ ja vihreiden kannattajat $(\mathrm{OR}=0,345,95 \% \mathrm{Cl} 0,205-0,579)$ olivat epäluuloisimpia somevaikuttajia kohtaan.

Sosiaali- ja terveysministeriön toimintaan koronakriisin käsittelyssä tyytymättömimpiä olivat miehet $\left(\mathrm{OR}=0,723^{\star * *}, 95 \% \mathrm{Cl} 0,616-0,875\right)$. Kaikkien muiden puolueiden kannattajat olivat tyytyväisempiä STM:n toimintaan kuin mitä perussuomalaisten kannattajat olivat, SDP:n kannattajat olivat kaikkein myönteisimpiä ( $\mathrm{OR}=6,315^{\star \star \star}, 95 \% \mathrm{Cl}$ 4,239 - 9,407), seuraavaksi myönteisimpiä olivat vasemmistoliiton kannattajat $\left(\mathrm{OR}=5,445^{\star \star *}, 95 \% \mathrm{Cl} 3,516\right.$ - 8,433). Ikäryhmistä 30-39-vuotiaat luottivat nuoria harvemmin viranomaisten rokotustietoon $\left(\mathrm{OR}=0,504^{*}, 95 \% \mathrm{Cl} 0,298-0,855\right)$, ja opistotasoisen tutkinnon tai alemman korkeakoulututkinnon $\left(\mathrm{OR}=1,423^{\star}, 95 \% \mathrm{Cl} 1,016-1,992\right)$ ja korkeakoulututkinnon $\left(\mathrm{OR}=2,173^{\star \star \star}, 95 \%\right.$ $\mathrm{Cl} 1,373$ - 3.440) suorittaneet luottivat viranomaisten rokotustietoon enemmän kuin näitä vähemmän kouluttautuneet. Puolueiden välisessä vertailussa kokoomuksen (OR 3,062***, $95 \% \mathrm{Cl} 1,589-5,899)$, vihreiden ( $\left.\mathrm{OR}=2,767^{\star \star \star}, 95 \% \mathrm{Cl} 1,482-5,165\right)$, SDP:n (OR = 3,061***, $95 \% \mathrm{Cl} 1,550-6,042)$ ja vasemmistoliiton kannattajat $\left(\mathrm{OR}=2,779^{\star *}, 95 \% \mathrm{Cl} 1,319-5,855\right)$ luottivat perussuomalaisten kannattajia todennäköisemmin viranomaisten rokotustietoon.

Yksilönvapauksien rajoittamisesta korona-aikana olivat huolissaan alle 30-vuotiaat (verrattuna 40-70-vuotiaisiin) ja alimpaan koulutusryhmään kuuluvat verrattuna opisto/AMKtasoisen tutkinnon suorittaneisiin ( $\left.\mathrm{OR}=0,647^{\star \star *}, 95 \% \mathrm{Cl} 0,495-0,847\right)$ sekä korkeakoulututkinnon suorittaneisiin ( $\left.\mathrm{OR}=0,615^{\star *}, 95 \% \mathrm{Cl} 0,436-0,867\right)$. Kun perussuomalaisten kannattajia verrattiin muiden puolueiden kannattajiin, vasemmistoliiton $\left(\mathrm{OR}=0,201^{\star \star *}, 95 \% \mathrm{Cl}\right.$ $0,096-0,420)$ ja vihreiden ( $\mathrm{OR}=0,359^{\star * *}, 95 \% \mathrm{Cl} 0,222$ - 0,580) kannattajat olivat harvemmin sitä mieltä, että yksilönvapauksia on rajoitettu liikaa.

\section{Pohdinta}

Enemmistö suomalaisista luotti huhtikuussa ja kesäkuussa 2020 kansallisiin instituutioihin (Suomen hallitus, tasavallan presidentti, sosiaali- ja terveysministeriö) sekä tiedeinstituutioihin (Terveyden ja hyvinvoinnin laitos ja yliopistot) koronakriisin hoidossa. Enemmistö myös 
pyrki noudattamaan viranomaisohjeita. Myös luottamus uutismediaan - Yle Uutisiin ja MTV Uutisiin - korona-asioista uutisoinnissa oli korkea. Johdonmukaisin ja voimakkain ennustava tekijä epäluottamukselle ja kielteiselle näkemykselle oli se, että kannatti perussuomalaisia. Lisäksi miehet ja vain peruskoulun, ammattikoulun tai vain lukion suorittaneet olivat epäluuloisimpia useita instituutioita kohtaan. Vastaavasti perussuomalaisten kannattajat, miehet ja nuoret vastaajat todennäköisimmin suosivat aktiivisia somevaikuttajia koronaepidemian ennustamisessa.

Jako suhtautumisessa THL:ää ja hallitusta kohtaan ei kulkenut hallituspuolue-oppositiopuolue-akselilla, vaan nimenomaan perussuomalaisten kannattajat erosivat muista puolueista, ja oppositiopuolue kokoomus muistutti monelta osin hallituspuolueita. Poikkeaman hallitus-oppositio-asetelmaan tekee myös se, että perussuomalaisten rinnalla keskusta ja SDP erottuivat korostaessaan koronarokotusten vapaaehtoisuutta, PS ja keskusta myös salliessaan koronarokotuksista kieltäytymisen. Siinä missä nyt raportoidussa tutkimuksessamme perussuomalaisten kannattajat erottuivat yksilönvapauksista huolestuneina, toisessa maaliskuun 2020 lopussa tehdyssä kyselyssä perussuomalaisten kannattajat (75\%) erosivat muiden puolueiden kannattajista eri tavalla: tuolloin he kaipasivat valtiolta tiukempia rajoituksia, kun taas vasemmistoliiton kannattajista vain 29 prosenttia, SDP:n ja vihreiden kannattajista noin kolmannes toivoi hallitukselta tiukempia rajoituksia (Yle 25.3.2020). Saattaa olla, että kriisin alkuvaiheessa suomalaisten suhtautuminen koronakriisin hoitamiseen haki vielä muotoaan. On myös mahdollista, että vastaajien näkemykset ovat ambivalentteja, toisin sanoen he saattavat samaan aikaan toivoa tiukempia rajoituksia ja olla huolestuneita yksilönvapauksista.

Kevään 2020 aikana tehtiin joitain muitakin koronakriisiin liittyviä kyselyitä suomalaisten parissa. Niiden tulokset ovat linjassa tässä artikkelissa raportoitujen tulosten kanssa. Toukokuussa tehdyssä kyselyssä luottamus Yle Uutisiin oli hieman vahvempaa (55\% luotti erittäin paljon, Matikainen ym. 2020) kuin nyt raportoidussa kyselyssä (huhtikuussa luotti $46 \%$ ja kesäkuussa 43\%). Suomalaisten luottamusta viranomaistahoihin kuvastaa myös THL:n 18.3.24.4.2020 välisenä aikana tekemän kyselyn tulos: vähintään kolme neljäsosaa suomalaisista luotti terveydenhoidon kykyyn hoitaa koronakriisi (Elovainio ym. 2020). Myös EVA:n kyselyssä selvä enemmistö suomalaisista antoi kyselyssä tukensa hallituksen järeille koronatoimille maalis-huhtikuun vaihteessa (Haavisto 2020).

Käytimme kyselyssä muutamaa samaa kysymystä kuin vuoden 2019 Tiedebarometrissä. Vertailusta voi varovaisesti päätellä kaksi asiaa: Ensiksikin korona-kevään aikana isompi osa suomalaisista (30\%) katsoi, että tieteeseen ei voi luottaa, koska saman alan asiantuntijat voivat olla asioista täysin eri mieltä, kuin ennen koronapandemiaa (17\%). Yksi selitys tälle saattaa olla, että koronaennusteista ja koronatoimista keskusteltiin ja kiisteltiin uutismediassa ja sosiaalisessa mediassa toistuvasti kevään 2020 aikana. Näin osa vastaajista on saattanut kokea tämän epävarmuuden ja kiistelyn osoituksena tieteen epäluotettavuudesta (vrt. Bucchi ja Saracino 2020).

Toiseksi, rokotuksen vapaaehtoisuus sai selvästi enemmän kannatusta korona-kevään aikana, kun rokotukset oli tarkennettu koronarokotuksiksi $(67,4 \%)$ kuin vuonna 2019, jolloin rokotuksista kysyttiin Tiedebarometrissä yleisellä tasolla ("Maksuttomien rokotusten tulee olla vapaaehtoisia", 29\%). Lisäksi kesäkuussa 2020 79,7 prosenttia luotti viranomaisten ja asiantuntijoiden antamaan tietoon rokotteista ja 70,5 prosenttia katsoi, että viranomaisten suosittelemista rokotteista kieltäytyminen on vastuutonta muita kohtaan. Vuoden 2019 Tie- 
debarometrissä vastaavat osuudet olivat hieman korkeammat, 89 prosenttia ja 85 prosenttia. On mahdollista, että rokotuskriittisyys ja vapaaehtoisuuden painotus ovat ylipäänsä lisääntyneet Suomessa. Kyse voi olla myös siitä, että osa vastaajista ei pitänyt koronaa niin vaarallisena, että sitä vastaan tarvitaan rokotus.

Entä kysymys rally around the flag -ilmiöstä? Mitä tulee tiedeinstituutioihin koskevaan luottamukseen, enemmistö suomalaisista oli jo ennen koronaepidemiaa jos ei nyt ihan lipun juurella, niin sen tuntumassa, jolloin koronapandemia ei merkittävällä tavalla voinut aiheuttaa tiukempaa ryhmittymistä lipun ympärille. Enemmistö myös luotti uutismediaan. Tuloksemme yhteisöllisestä vastuusta ja yksilönvapauksien rajoittamisen hyväksymisestä yhteisön terveyden hyväksi kertovat solidaarisuudesta ainakin asenteiden tasolla, vaikka käytännön toteutuksessa tilanne saattaa olla toisenlainen. Tuloksemme viittaavat myös siihen suuntaan, että luottamus keskeisiä instituutioita kohtaan korreloi keskenään. Tällaisia tahoja ovat ainakin Suomen hallitus, tasavallan presidentti, THL, STM ja Yle Uutiset, jotka olisivat tämän luotettavien instituutioiden ryhmän. Myös Saarinen ja kumppanit (2020, 162) raportoivat, että luottamus poliittisiin instituutioihin on yhteydessä yliopistoja ja Yleisradiota kohtaan tunnettuun luottamukseen koko väestössä, mutta myös eri puolueiden sisällä (emt., 161-162, ks. myös Tiedebarometri 2019).

Kiinnostava yksityiskohta paljastuu koronarokotuksiin liittyvistä näkemyksistä: melkein kolme neljästä arvioi, että viranomaisten suosittelemista rokotteista kieltäytyminen on vastuutonta, mutta lähes yhtä moni katsoi, että koronarokotusten on oltava vapaaehtoisia. Varsinaiseen pakottamiseen ei siten koronankaan aikana haluta mennä, vaan ideaalina saattaa olla kansalainen, joka vapaaehtoisesti oivaltaa toimia vastuullisesti.

Yhdenlaista rally around the flag -ilmiötä lienee myös keväällä 2020 "talvisodan hengen" peräänkuuluttamiset (esimerkiksi Sotaveteraaniliitto Twitterissä 22.3.2020, Länsi-Suomi 13.3.2020, Alastalo 2.4.2020). Sama toistui 30.11.2020 talvisodan alkamisen vuosipäivänä, kun kirjailija Jari Tervo kirjoitti Twitterissä:

81 vuotta sitten Neuvostoliitto hyökkäsi Suomeen. Alkoi talvisota. Meiltä vaadittiin paljon.

Yli 25000 suomalaista kuoli. Nyt meidän pitäisi käyttää maskia, pestä käsiä ja karttaa väenpaljouksia. Ei ole paljon vaadittu.

Suomalaisia kutsutaan yhteisen hyvän vuoksi noudattamaan sääntöjä ja laittamaan omat halut hetkeksi syrjään.

On kiinnostavaa, että myös Ruotsissa (Bohlin 2020) ja Italiassa (Bucchi ja Saracino 2020) tehdyissä kyselyissä on havaittu varsin korkeaa luottamusta kansallisiin viranomaisiin ja asiantuntijainstituutioihin, vaikka näissä epidemian kulku ja kansalliset toimet epidemian hallinnassa ovat eronneet paikoin selkeästi Suomen vastaavista. Lisäksi, vaikkapa Ruotsin koronapolitiikkaa tarkasteltaessa, voidaan myös pohtia, voiko vahva luottamus - on se sitten luottamusta instituutioihin tai luottamusta toisiin kansalaisiin - johtaa myös riskien aliarviointiin (vrt. Devine ym. 2020, 4).

Aikaisempi tutkimus (Väliverronen ym. 2020) ja havaintomme sosiaalisessa mediassa aktiivisten terveysvaikuttajien toiminnasta (Eroon koronasta 2020; Heikkilä 2020; Nordin 2020) viittavat siihen, että Suomessakin on liikehdintää, jossa THL:n ja Suomen hallituksen koronalinjauksia haastetaan voimakkaasti. Tällaiset havainnot ovat todennäköisesti 
osin heijastusta laajemmista ilmiöistä: 2010-luvun jälkipuoliskolla asiantuntijoiden kritiikki ja kyseenalaistaminen nousivat vahvasti yhteiskunnalliseen keskusteluun. Jotkut puhuivat jopa asiantuntijuuden kuolemasta (Nichols 2017). Alettiin puhua totuuden jälkeisestä ajasta, perinteisen uutismedian kriisistä ja valeuutisten lisääntyvästä merkityksestä (esim. Vihma ym. 2018), oli sitten kysymys vaaleista tai rokotuksista.

Kuten aiemmin totesimme, uutismediassa ja erityisesti sosiaalisessa mediassa varsinkin THL:ään kohdistui voimakasta kritiikkiä. Tämän tutkimuksen valossa tämä kriittisyys ei korostu kansalaisten kyselyissä ilmaisemissa asenteissa. Tämä kertoo siitä, että asiantuntijakriittisyys ja luottamus ovat varsin kompleksisia ilmiöitä, joita yksioikoiset väitteet totuudenjälkeisestä ajasta tai asiantuntijuuden kuolemasta eivät tavoita. Lisäksi luottamusta, kuten muitakin kyselytutkimuksissa mitattavia ilmiöitä koskevia tuloksia pohtiessa on hyvä muistaa, ettei luottamus ole käsitteenä yksiselitteinen ja helposti tulkittavissa (Devine ym. $2020,2)$. Mielipidetutkimuksissa ilmaistu luottamus voi heijastella eri tavalla arvioitua luottamusta. Lisäksi tiedettä koskevaa luottamusta arvioitaessa on tärkeä muistaa, että tiede yleensä, erilliset tieteenalat tai tutkimussuuntaukset saatetaan arvioida hyvin eri tavoilla ja perustein. Näin siis esimerkiksi tässä esitettyjen THL:ää tai yliopistoja koskevien tulosten takana voi olla varsin erilaisia havaintoja ja pohdintoja kyseisten laitosten ja niiden edustajien toiminnasta. On esimerkiksi mahdollista, että osa perustaa arvionsa THL:n toimintaan sikainfluenssan aikana tai muiden kiistojen kuten alkoholipolitiikkaan liittyvien kiistojen aikana (ks. Väliverronen ym. 2020). Toiset puolestaan arvioivat pikemminkin THL:n edustajien esiintymisiä mediassa kevään 2020 aikana. On siis mahdollista, että osalla kansalaisista esimerkiksi luottamus THL:ään pysyy korkeana, oli sitten kyse ravitsemusneuvoista tai koronapandemiasta. Ja edelleen, koronaepidemian aikana kertyneet luottamuksen tai epäluottamuksen kokemukset saattavat heijastua luottamukseen myös tulevien epidemioiden kohdalla.

Nyt raportoidut tulokset huhti- ja kesäkuulta 2020 eivät tue ajatusta, että viime vuosina tai erityisesti koronakevään aikana kriittisyys asiantuntijoita tai THL:n kaltaisia asiantuntijaviranomaisia kohtaan olisi merkittävästi lisääntynyt. Merkittävä osa suomalaisista luotti perinteisiin auktoriteetteihin, kuten THL:ään, STM:ään, yliopistoihin ja Yle Uutisiin. Enemmistö myös hyväksyi yksilönvapauksien rajoitukset korona-aikana. Tutkimuksemme kuitenkin osoitti, että osa suomalaisista on johdonmukaisen epäluuloisia kansallisia tiede- ja viranomaisinstituutioita kohtaan. Osa ei luottanut näihin tahoihin, piti tietoja koronan vaarallisuudesta liioiteltuina ja oli huolissaan yksilönvapauksien rajoituksista korona-aikana.

Tutkimuksemme osoitti luottamuksen ja näkemysten pysyneen suhteellisen tasaisina kevään 2020, mutta joitain muutoksia ilmeni. Nämä muutokset viittaavat siihen, että edellä esitetty niin kutsuttu lipun alle ryhmittyminen olisi heikentynyt ja yksilönvapauksien korostaminen lisääntynyt koronatilanteen helpotettua kesäkuuhun mennessä. Vahvasti Suomen hallituksen, STM:n ja tasavallan presidentin koronatoimiin luottaneiden osuus laski hieman. Huoli yksilönvapauksien rajoittamisesta lisääntyi jonkin verran ja huoli viranomaisten ohjeista piittaamattomista puolestaan väheni. Nämä muutokset saattavat heijastella koronatilanteen helpottumista - käsitys viruksen vaarallisuudesta alkoi lieventyä ja yksilöille oli mahdollista sallia vapauksia kesäkuussa huhtikuuta enemmän.

Tulostemme perusteella perussuomalaisten kannattajat erottuivat systemaattisesti muiden puolueiden kannattajista THL:n, STM:n, Suomen hallituksen ja Yle Uutisten kriitikkoina 
ja sosiaalisen median vaikuttajien kannattajina. Heitä ei kuitenkaan pidä yksioikoisesti leimata tiedevastaiseksi liikkeeksi. Jopa heidän keskuudessaan oli merkittävä joukko vastaajia, jotka eivät lukeutunut kriitikoihin: Perussuomalaisten kannattajista 39 prosenttia arvioi, että THL on hoitanut koronakriisin hyvin. Yhtä moni arvioi, että Suomen hallitus on hoitanut koronakriisin hyvin ja vain reilu viidennes luotti somevaikuttajiin enemmän kuin terveysviranomaisiin.

Tätä tulkintaa tukee aikaisempien tutkimusten havainto, että oikeistopopulistien kritiikki ei kohdistu kaikkeen tieteeseen tai tieteeseen kokonaisuutena, vaan luottamus ja kritiikki ovat valikoivia. Näin ollen kritiikki kohdistuu tiettyihin tutkimusaloihin ja -aiheisiin, kuten ilmastonmuutos, rokotukset, terveystutkimus, maahanmuutto ja monikulttuurisuus (Väliverronen ja Saikkonen 2020). Tuukka Ylä-Anttila (2018) on tutkimuksessaan kahdesta suomalaisesta, osin perussuomalaisiin kytköksissä olevasta populistisesta verkkofoorumista osoittanut, että vaikka osa näiden verkkosivujen keskusteluista edustaa tyypillistä tieteen kieltämistä tai salaliittoteorioita, osa verkkosivujen keskustelijoista puolestaan argumentoi "eräänlaista objektiivisista vasta-asiantuntijuutta" (emt., 358). Esimerkiksi he kritisoivat feminististä tutkimusta tai sukupuolentutkimusta ei-positivistisena ja epärationaalisena ja peräänkuuluttavat tilastollisiin menetelmiin nojautuvaa tiedettä, eli argumentoivat perinteisten luonnontieteen ideaalien puolesta.

Lopuksi pari huomiota tutkimuksemme puutteista: Kyselyaineisto oli kohtuullisen edustava otos Manner-Suomessa asuvista kansalaisista sukupuolen ja iän suhteen. Koulutuksen suhteen perus-, kansa- tai keskikoulun suorittaneet olivat aliedustettuina. Tämä saattaa vaikuttaa tuloksiimme, sillä juuri tämä ryhmä oli koulutusryhmistä myönteisin somevaikuttajia ja kriittisin hallituksen korona-arvioita kohtaan ja epäluuloisin koronarokotusta kohtaan. Edustavuuden ongelmiin luottamusta tieteeseen koskevissa kyselyissä on kiinnitetty ennenkin huomiota (Suhonen 2016). On siis mahdollista, että tieteeseen ja asiantuntijoihin epäilevästi suhtautuvien osuus on todellisuudessa jonkin verran nyt raportoitua suurempi. Tulevissa tutkimuksissa olisikin paneuduttava nimenomaan näissä kuluttajapaneeleissa ja väestökyselyissä varjoon jääviin ryhmiin. Äänestysaikomus mitattiin lähes vuosi ennen ensimmäistä kyselyä, joten osalla vastaajista puoluepreferenssi on saattanut muuttua heinäkuun 2019 jälkeen. Toisaalta äänestysaikomusten ja asenteiden suhde oli samansuuntainen kuin aikaisemmissa tutkimuksissa, joten tuloksemme vaikuttavat luotettavilta tältä osin.

Syksyllä 2020 Suomessa alkoi epidemian toinen aalto ja joulukuun lopussa aloitettiin koronarokotukset. Julkinen keskustelu oikeanlaisista hallintatoimista ja niiden ajoituksesta sekä luottamuksesta asiantuntijoihin ja poliitikkoihin on jatkunut. Rokotusohjelman käynnistyttyä erityisesti rokotusten turvallisuus, rokottamisen nopeus ja rokotusskeptisyys ovat olleet mediassa esillä. Myös hallituksen ja terveysviranomaisten kritiikki on jatkunut.

\section{Kiitokset}

Kiitos Tieteen tiedotus ry:lle, jonka tuki mahdollisti kyselyjen tekemisen. Tutkimus on osa Suomen Akatemian Media ja yhteiskunta -ohjelman rahoittamaa Mediating expertise and scientific knowledge in public debates on health -hanketta (320278 ja 320279) sekä Helsingin Sanomain Säätiön rahoittamaa Koronakriisin julkinen dynamiikka -hanketta. 


\section{Viitteet}

1 Valinta tehtiin hyödyntämällä kyselyn tuloksia seuraavasti: Kyselyssä kysyttiin myös "Mistä lähteistä haet ensi sijassa tietoa koronavirukseen ja pandemiaan liittyen? Valitse itsellesi tärkein". Suosituin vaihtoehto oli molemmissa mittauksissa "Televisio ja radio" (40\% ja 37\%), kun taas seuraavaksi tärkeimmät mediat olivat selvästi vähemmän tärkeitä: joka neljännelle tärkein oli viranomaisorganisaatioiden verkkosivut ja 14 prosentille (huhtikuu) ja 18 prosentille (kesäkuu) sanomalehdet olivat tärkein lähde. Myös Matikainen ja kumppanit $(2020,85)$ ovat raportoineet vastaavasti: Uutismedioiden verkkosivut ja mobiilisovellukset televisiouutiset ja television suorat korona-erikoislähetykset olivat enemmistölle suomalaisista tärkeitä uutislähteitä koronakriisissä.

\section{Kirjallisuus}

Alastalo, Simo. 2020."Pikkuisen talvisodan henkeä" - Nyt puhuu Suomea koronan jälkeiseen aikaan johdattavan selvitysryhmän johtaja. Demokraatti 2.4.2020. Luettu 30.11.2020. https://demokraatti.fi/pikkuisen-talvisodanhenkea-nyt-puhuu-suomea-koronan-jalkeiseen-aikaan-johdattavan-selvitysryhman-johtaja.

Bangerter, Adrian, Franciska Krings, Audrey Mouton, Ingrid Gilles, Eva G.T. Green ja Alain Clémence. 2012. "Longitudinal Investigation of Public Trust in Institutions Relative to the $2009 \mathrm{H} 1 \mathrm{~N} 1$ Pandemic in Switzerland." PLOS ONE 7 (11): e49806. https://doi.org/10.1371/journal.pone.0049806.

Bangerter, Adrian. 2014. "Investigating and rebuilding public trust in preparation for the next pandemic." European Psychologist 19 (1): 1-3. https://doi.org/10.1027/1016-9040/aooo173.

Bauer, Martin, Nick Allum ja Steve Miller. 2007. "What can we learn from 25 years of PUS survey research?" Public Understanding of Science 16 (1): 71-95. https://doi.org/10.1177/0963662506071287.

Bavel, Jay, Katherine Baicker, Paulo Boggio ym. 2020. "Using social and behavioural science to support COVID-19 pandemic response." Nature Human Behaviour 4: 46o-471. https://doi.org/10.1038/s41562-020-0884-z.

BBC. 30.8.2020. Germany coronavirus: Hundreds arrested in German 'anti-corona' protests. Luettu 1.2.2021. https://www.bbc.com/news/world-europe-53959552.

Beck, Ulrich. 1994. "The reinvention of politics: Towards a theory of reflexive modernization." Teoksessa Reflexive modernization, Politics, Tradition and aesthetics in the modern social order, toimittaneet Beck, Ulrich, Anthony Giddens ja Scott Lash, 1-55. Cambridge: Polity Press.

Blair, Robert, Benjamin Morse ja Lily Tsai. 2016. "Public Health and Public Trust: Evidence from the Ebola Virus Disease Epidemic in Liberia." MIT Political Science Department Research Paper No. 2018-6. http://dx.doi.org/10.2139/ssrn.2864029.

Blank, Joshua ja Daron Shaw. 2015. "Does partisanship shape attitudes toward science and public policy? The case for ideology and religion." The Annals of the American Academy 658, 18- 35 . https://doi.org/10.1177/0002716214554756.

Bohlin, Gustav. 2020. "Coronavirus in the Swedish media study - high public confidence in researchers and healthcare professionals." Vetenskap Q Allmänhet 02.04.2020. Luettu 1.12.2020. https://v-a.se/2020/04/ coronavirus-in-the-swedish-media-study-high-public-confidence-in-researchers-and-healthcareprofessionals/.

Bol, Damien Marco Giani, Andre Blais ja Peter John Loewen. 2020. "The effect of covid-19 lockdowns on political support: Some good news for democracy?" European Journal of Political Research. https://doi.org/10.1111/1475-6765.12401.

Bucchi, Massimiano ja Barbara Saracino. 2020. Scared, Supportive and Confident in Science (but a little confused by expert communication). Trends and changes in the perception of the pandemic: the new data from the Science in Society Monitor. Public Understanding of Science blog 19.4.2020. Luettu 1.2.2021. https://sagepus.blogspot.com/2020/04/italian-citizens-and-covid-19-one-month.html.

Castell, Sarah, Anne Charlton, Michael Clemence, Nick Pettigrew, Sarah Pope, Anne Quigley, Jayes Navin Shah, ja Tim Silman. 2014. Public attitudes to science 2014: Main Report. Lontoo: Ipsos MORI Social Research Institute.

Cinelli, Matteo, Walter Quattrociocchi, Alessandro Galeazzi, Carlo Valensise, Emanuele Brugnoli, Ana Lucia Schmidt, Paola Zola, Fabiana Zollo ja Antonio Scala. 2020. "The covid-19 social media infodemic." Scientific Reports 10: 16598. https://doi.org/10.1038/s41598-020-73510-5.

Devine, Daniel, Jennifer Gaskel, Will Jennings ja Gerry Stoker. 2020. "Trust and the Coronavirus Pandemic: What Are the Consequences of and for Trust?" Political Studies Review (August 2020): 1-12. https://doi.org/10.1177/1478929920948684.

Elovainio, Marko, Karoliina Tiuraniemi, Vesa Jormanainen ja Timo Partonen. 2020. "Koronatautiepidemia: terveyshuolet ja uni." Tutkimuksesta tiiviisti 10/2020. Terveyden ja hyvinvoinnin laitos. Luettu 1.2.2021. https://www.julkari.fi/bitstream/handle/10024/140017/URN_ISBN_978-952-343-513-1.pdf. 
Eroon koronasta. 2020. Vapaaksi koronasta -työryhmän muistio. 15.5.2020. Luettu 30.11.2020. https://www.eroonkoronasta.fi/muistio.

Evans, Jules. 2020. 'Conspirituality' - the overlap between the New Age and conspiracy beliefs. Medium, 17.4.2020. Luettu 30.11.2020. https://medium.com/@julesevans/conspirituality-the-overlap-between-thenew-age-and-conspiracy-beliefs-co305eb92185.

Gauchat, Gordon. 2012. "Politicization of science in the public sphere: a study of public trust in the United States, 1074 to 2010." American Sociological Review 77 (2): 167-187. https://doi.org/10.1177/0003122412438225.

Giddens, Anthony. 1991. Modernity and self-identity. Cambridge: Polity Press.

Haavisto, Ilkka. 2020. Politiikan poikkeustila. Koronakriisi yhdisti suomalaiset. Eva-analyysi nr. 81. Helsinki: Elinkeinoelämän Valtuuskunta EVA.

Heikkilä, Antti. 2020. Covid-19 vedätys. Antti Heikkilän terveysklubi 25.5.2020. Luettu 1.12.2020. https://www.anttiheikkila.com/blogi/covid-19-vedatys/.

House of Lords. 2000. House of Lords Select Committee on Science and Technology. 3rd Report 2000. Lontoo: HL Paper 38.

HS. 12.4.2020. Pääkirjoitus. Vaikeina aikoina tarvitaan sekä yksituumaisuutta että oppositiota. Luettu 1.2.2021. https://www.hs.fi/paakirjoitukset/art-2000006472302.html.

Jallinoja, Piia, Mikko Jauho ja Johanna Mäkelä. 2016. "Newspaper debates on milk fats and vegetable oils in Finland, 1978-2013: An analysis of conflicts over risks, expertise, evidence and pleasure." Appetite 105: 274-82. https://doi.org/10.1016/j.appet.2016.05.035.

Jennings, Will. 2020. Covid-19 and the 'Rally-Round-the Flag' Effect, UK in a Changing Europe. Luettu 1.12.2020. https://ukandeu.ac.uk/covid-19-and-the-rally-round-the-flag-effect/.

Järvi, Ulla. 2010. Media terveyden lähteillä. Miten sairaus ja terveys rakentuivat 200o-luvun mediassa. Jyväskylä: Jyväskylä Studies in Humanities, Jyväskylän yliopisto.

Kata, Anna. 2012. "Anti-vaccine activists, web 2.0 and the postmodern paradigm - An overview of tactics and tropes used online by the anti-vaccination movement." Vaccine 30 (25): 3778-3789. https://doi.org/10.1016/j.vaccine.2011.11.112.

Lanska, Douglas J. 1998. "The Mad Cow Problem in the UK: Risk Perceptions, Risk Management, and Health Policy Development." Journal of Public Health Policy 19 (2): 160-183. https://doi.org/10.2307/3343296.

Larson, Heidi ja David Heymann. 2010. "Public Health Response to Influenza $A\left(\mathrm{H}_{1} \mathrm{~N} 1\right)$ as an Opportunity to Build Public Trust." JAMA 303 (3): 271-272. https://doi.org/10.1001/jama.2009.2023.

Länsi-Suomi. 13.03.2020. Näkökulma: Koronaepidemian aattona Ruotsinlaivat kulkevat ja Triplassa shoppaillaan - Pääministeri Sanna Marin voisi toimia ilman valmiuslakiakin. Luettu 1.2.2021. https://ls24.fi/ lannen-media/kommentti-koronaepidemian-aattona-ruotsinlaivat-kulkevat-ja-triplassa-shoppaillaanpaaministeri-sanna-marin-voisi-toimia-ilman-valmiuslakiakin.

Matikainen, Janne, Markus Ojala, Minna Horowitz ja Johanna Jääsaari. 2020. Media ja yleisön luottamuksen ulottuvuudet: Instituutiot, journalismi ja mediasuhde. Helsinki: Helsingin yliopisto.

McCright, Aaron, Katherine Dentzman, Meghan Charters ja Thomas Dietz. 2013. "The influence of political ideology on trust in science." Environmental Research Letters 8 (4): 1-9. https://doi.org/10.1088/1748-9326/8/4/044029.

McIntyre, Lee. 2018. Post-Truth. Cambridge, MA: MIT Press Essential Knowledge Series.

Mueller, John. 1970. "Presidential Popularity from Truman to Johnson." American Political Science Review 64 (1): 18-34. https://doi.org/10.2307/1955610.

Muirhead, Russell ja Nancy Rosenblum. 2019. A Lot of People are Saying: The New Conspiracism and the Assault on Democracy. Princeton: Princeton University Press. https://doi.org/10.1057/s41296-019-00372-6.

National Science Foundation. 2018. Science and Engineering Indicators 2018. Science and Technology: Public Attitudes and Understanding. Luettu 1.2.2021. https://www.nsf.gov/statistics/2018/nsb20181/assets/404/ science-and-technology-public-attitudes-and-understanding.pdf.

Nichols, Thomas. 2017. The death of expertise: The campaign against established knowledge and why it matters. New York: Oxford University Press.

Noppari, Elina ja IImari Hiltunen. 2018. "Populistinen vastamedia eliittejä haastamassa." Teoksessa Media ja populismi. Työkaluja kriittiseen journalismiin, toimittaneet Niemi, Mari K. ja Topi Houni, 236-272. Tampere: Vastapaino.

Nordin, Maria. 2020. Pelko on vaarallista. Toivotan päättäjille tyyneyttä ja rohkeutta nähdä pelon ja ylireagoinninnseuraukset ja tehdä rohkeita päätöksiä nyt. @MariaNordin 29.04.2020. Luettu 1.2.2021. https://twitter.com/MariaNordin/status/1255391659199729664. 
Norris, Pippa ja Ronald Inglehart. 2019. Cultural Backlash. Trump, Brexit and Authoritarian Populism. Cambridge: Cambridge University Press.

Oksanen, Atte, Markus Kaakinen, Rita Latikka, lina Savolainen, Nina Savela ja Aki Koivula. 2020. "Regulation and Trust: 3-Month Follow-up Study on COVID19 Mortality in 25 European Countries." JMIR Public Health and Surveillance 6 (2): e19218. https://doi.org/10.2196/19218.

Puumalainen, Taneli, Hanna Nohynek ja Veikko Launis. 2015. "Onko Suomi muuttumassa rokotuskriittiseksi?" Suomen Lääkärilehti 70 (36): 2222-2223.

Reunanen, Esa, toim. 2020. Uutismedia verkossa (2020) - Reuters-instituutin Digital News Report Suomen maaraportti. Journalismin, viestinnän ja median tutkimuskeskus. Tampereen yliopisto. Luettu 1.2.2021. https://trepo.tuni.fi/bitstream/handle/10024/122596/978-952-03-1610-5.pdf.

Saarikoski, Saska. 2020. Kun hätä on suurin, kansa seuraa johtajaa. Helsingin Sanomat 19.3.2020. Luettu 1.2.2021. https://www.hs.fi/mielipide/art-2000006444291.html.

Saarinen, Arttu, Aki Koivula ja Teo Keipi. 2018. "Eri puolueiden kannattajien suhtautuminen suomalaiseen tieteeseen ja tutkimukseen." Tiedepolitiikka 43 (1): 18-31.

Saarinen, Arttu, Aki Koivula ja Teo Keipi. 2020. "Political trust, political party preference and trust in knowledgebased institutions." International Journal of Sociology and Social Policy 40 (1/2): 154-168. https://doi.org/10.1108/IJSSP-06-2019-0113.

Sadeoja, Tapio. 2020. Mika Salminen - mies, jota kukaan ei haluaisi nähdä. Ilta-Sanomat 5.5.2020. Luettu 1.2.2021. https://www.is.fi/kotimaa/art-2000006497661.html.

Setälä, Vienna ja Esa Väliverronen. 2014. "Fighting fat: the role of 'field experts' in mediating science in health communication." Science as Culture 23 (4): 517-536. https://doi.org/10.1080/09505431.2014.905526.

Sotaveteraaniliitto. 2020. Nyt järki päähän siellä \#hiihtoloma'lle hinkuvien ruuhkauttamalla nelostielläkin. Älä ole joukkotuhoase. \#pysykotona. \#koronavirus \#koronafi \#talvisodanhenki \#himmetäeimuistotsaa. @ sotaveteraanit 22.3.2020 Luettu 24.3.2021 https://twitter.com/sotaveteraanit/status/1241603970566705152.

Suhonen, Pertti. 2016. Tiedebarometri ei todista kansan luottamusta tieteeseen. Helsingin Sanomat, mielipide 25.11. 2016.

THL, Terveyden ja hyvinvoinnin laitos. 2011. Kansallisen narkolepsiatyöryhmän loppuraportti. Luettu 1.2.2021. https://www.julkari.fi/bitstream/handle/10024/80009/c02a3788-a691-47a4-bca8-5161b6cffo77.pdf.

Tiedebarometri. 2019. Tutkimus suomalaisten suhtautumisesta tieteeseen ja tieteellis-tekniseen kehitykseen. Tieteen tiedotus ry. Luettu 1.2.2021. https://www.tieteentiedotus.fi/files/Tiedebarometri_2019.pdf.

Tiirinki, Hanna, Liina-Kaisa Tynkkynen, Markku Sovala, Salla Atkins, Meri Koivusalo, Pauli Rautiainen, Vesa Jormanainen ja IImo Keskimäki. 2020. "COVID-19 pandemic in Finland - Preliminary analysis on health system response and economic consequences." Health Policy and Technology 9 (4): 649-662. https://doi.org/10.1016/j.hlpt.2020.08.005.

Ukkola, Sanna. 2020. Tätä vauhtia kymmenet tuhannet suomalaiset kuolevat koronaan - miksi Suomi ei yritä estää sitä? Iltalehti 12.3.2020. Luettu 1.2.2021: https://www.iltalehti.fi/koronavirus/a/c1c3e82f-58fb-430ca619-4fb74eeb6837.

Vihma, Antto, Jarno Hartikainen, Hannu-Pekka Ikäheimo ja Olli Seuri. 2018. Totuuden jälkeen. Miten media selviää algoritmien ja paskapuheen aikana. Helsinki: Teos.

Väliverronen, Esa. 2016. Julkinen tiede. Tampere: Vastapaino.

Väliverronen, Esa. 2021. "Asiantuntijuuden murros ja luottamus instituutioihin koronakriisissä." Teoksessa Hyvä ja paha tieto, toimittaneet Ilari Hetemäki, Anna-Kaisa Kuusisto, Maria Lähteenmäki ja Esa Väliverronen, 111123. Helsinki: Gaudeamus.

Väliverronen, Esa, Jonas Sivelä ja Hanna Nohynek. 2020. "Suomalaisten suhde rokotuksiin - mitä tuoreet kyselytutkimukset kertovat." Sosiaalilääketieteellinen aikakauslehti 57 (3): 256-265. https://doi.org/10.2399o/sa.92093.

Väliverronen, Esa ja Sampsa Saikkonen. 2020. "Freedom of expression challenged: Scientists' views on hidden forms of suppression and self-censorship." Science, Technology Q Human Values. https://doi.org/10.1177/0162243920978303.

Väliverronen, Esa, Salla-Maaria Laaksonen, Mikko Jauho ja Piia Jallinoja. 2020. "Liberalists and data-solutionists: redefining expertise in Twitter debates on coronavirus in Finland." Journal of Science Communication 19 (5): A10 1-21. https://doi.org/10.22323/2.19050210.

Walker, Patrick; Charlie Whittaker, Oliver Watson, Marc Baguelin, Kylie Ainslie, Sangeeta Bhatia, (...) ja Azra Ghani. 2020. Report 12: The global impact of COVID-19 and strategies for mitigation and suppression. WHO Collaborating Centre for Infectious Disease Modelling, MRC Centre for Global Infectious Disease Analysis, Abdul Latif Jameel Institute for Disease and Emergency Analytics, Imperial College London. Luettu 2.12.2020. https://www.imperial.ac.uk/media/imperial-college/medicine/sph/ide/gida-fellowships/ Imperial- College-COVID19-Global-Impact-26-03-2020.pdf . 
Wellcome Global Monitor. How does the world feel about science and health. 2019. Wellcome Trust, Lontoo. Luettu 1.2.2021. https://wellcome.ac.uk/reports/wellcome-global-monitor/2018.

Yle. 25.3.2020. Ylen kysely: Lähes puolet suomalaisista haluaa vieläkin tiukempia rajoituksia, ani harva pitää nykytoimia ylimitoitettuna. Luettu 1.2.2021. https://yle.fi/uutiset/3-11274639.

Ylä-Anttila, Tuukka. 2018. "Populist knowledge: 'Post-truth' repertoires of contesting epistemic authorities." European Journal of Cultural and political Sociology 5 (4): 356-388.

https://doi.org/10.108o/23254823.2017.1414620. 